\title{
Environmental impacts of genetically modified (GM) crop use 1996-2015: Impacts on pesticide use and carbon emissions
}

\author{
Graham Brookes and Peter Barfoot (1) \\ PG Economics, Dorchester, UK
}

\begin{abstract}
This paper updates previous assessments of important environmental impacts associated with using crop biotechnology in global agriculture. It focuses on the environmental impacts associated with changes in pesticide use and greenhouse gas emissions arising from the use of GM crops since their first widespread commercial use in the mid-1990s. The adoption of GM insect resistant and herbicide tolerant technology has reduced pesticide spraying by 618.7 million $\mathrm{kg}$ $(-8.1 \%)$ and, as a result, decreased the environmental impact associated with herbicide and insecticide use on these crops (as measured by the indicator, the Environmental Impact Quotient (EIQ)) by $18.6 \%$. The technology has also facilitated important cuts in fuel use and tillage changes, resulting in a significant reduction in the release of greenhouse gas emissions from the GM cropping area. In 2015, this was equivalent to removing 11.9 million cars from the roads.
\end{abstract}

KEYWORDS. active ingredient, biotech crops, carbon sequestration, environmental impact quotient, GMO, no tillage, pesticide

\section{INTRODUCTION}

GM crop technology has been widely used since the mid 1990s in several countries and has mainly been used in 4 main crops; canola, maize, cotton and soybean. In 2015, crops containing this type of technology accounted for $48 \%$ of the global plantings of these crops. In addition, small areas of GM sugar beet (adopted in the USA and Canada since 2008), papaya (in the USA since 1999 and China since 2008), alfalfa (in the US initially in 2005-2007 but latterly since 2011), squash (in the USA since 2004) and brinjal (in Bangladesh since 2015) have been planted.

The main traits so far commercialised convey:

- Tolerance to specific herbicides (notably to glyphosate and to glufosinate) in maize, cotton, canola (spring oilseed rape), soybean, sugar beet and alfalfa. This GM herbicide tolerant (GM HT) technology allows for the 'over the top' spraying of

Correspondence to: Graham Brookes; PG Economics Ltd, Stafford House, 10 Prince of Wales Rd, Dorchester, Dorset DT1 1PW, UK; Email: graham.brookes@btinternet.com

Received February 10, 2017; Revised March 13, 2017; Accepted March 17, 2017.

(c) 2017 Graham Brookes and Peter Barfoot.

This is an Open Access article distributed under the terms of the Creative Commons Attribution-NonCommercial-NoDerivatives License (http://creativecommons.org/licenses/by-nc-nd/4.0/), which permits non-commercial re-use, distribution, and reproduction in any medium, provided the original work is properly cited, and is not altered, transformed, or built upon in any way. 
GM HT crops with these specific broadspectrum herbicides, that target both grass and broad-leaved weeds but do not harm the crop itself;

- Resistance to specific insect pests of maize, cotton, soybeans and brinjal. This GM insect resistance (GM IR), or 'Bt' technology offers farmers resistance in the plants to major pests such as stem and stalk borers, earworms, cutworms and rootworm (eg, Ostrinia nubilalis, Ostrinia furnacalis, Spodoptera frugiperda, Diatraea spp, Helicoverpa zea and Diabrotica spp) in maize, bollworm/budworm (Heliothis sp and Helicoverpa) in cotton and caterpillars (Helicoverpa armigeru) in soybeans.

In addition, the GM papaya and squash referred to above are resistant to important viruses (eg, ringspot in papaya).

This paper presents an assessment of some of the key environmental impacts associated with the global adoption of these GM traits. The environmental impact analysis focuses on:

- Changes in the amount of insecticides and herbicides applied to the GM crops relative to conventionally grown alternatives and;

- The contribution of GM crops toward reducing global greenhouse gas (GHG) emissions.

- It is widely accepted that increases in atmospheric levels of greenhouse gases such as carbon dioxide, methane and nitrous oxide are detrimental to the global environment (see for example,Intergovernmental Panel on Climate Change (2006 Intergovernmental Panel on Climate Change)). Therefore, if the adoption of crop biotechnology contributes to a reduction in the level of greenhouse gas emissions from agriculture, this represents a positive development for the world.

The study integrates data for 2015 into the context of earlier developments and updates the findings of earlier analysis presented by the authors. (Brookes \& Barfoot, 2006, Brookes \& Barfoot, 2007, Brookes \& Barfoot, 2008, Brookes \& Barfoot, 2010, Brookes \& Barfoot, 2011, Brookes \&
Barfoot, 2012, Brookes \& Barfoot, 2013, Brookes \& Barfoot, 2014, Brookes \& Barfoot, 2015)

The methodology and analytical procedures in this present discussion are unchanged to allow a direct comparison of the new with earlier data (readers should however, note that some data presented in this paper are not directly comparable with data presented in previous analysis because the current paper takes into account the availability of new data and analysis, including revisions to data for earlier years), and to save readers the chore of consulting these earlier papers for details of the methodology and arguments, these elements are included in full in this updated paper.

The aim has been to provide an up to date and as accurate as possible assessment of some of the key environmental impacts associated with the global adoption of GM crops. It is also hoped the analysis continues to make a contribution to greater understanding of the impact of this technology and facilitates more informed decision-making, especially in countries where crop biotechnology is currently not permitted.

\section{RESULTS AND DISCUSSION}

\section{Results: Environmental Impacts of Insecticide and Herbicide Use Changes}

\section{HT Crops}

A key impact of GM HT (largely tolerant to glyphosate) technology use has been a change in the profile of herbicides typically used. In general, a fairly broad range of, mostly selective (grass weed and broad-leaved weed) herbicides has been replaced by one or 2 broad-spectrum herbicides (mostly glyphosate) used in conjunction with one or 2 other (complementary) herbicides (eg, 2 4,D). This has resulted in:

Aggregate reductions in both the volume of herbicides used (in terms of weight of active ingredient applied) and the associated field EIQ values when compared with usage on conventional (non GM) crops in some countries, indicating net improvements to the environment (for an explanation of the EIQ indicator, see the methodology section); 
In other countries, the average amount of herbicide active ingredient applied to GM HT crops represents a net increase relative to usage on the conventional crop alternative. However, even though the amount of active ingredient use has increased, in terms of the associated environmental impact, as measured by the EIQ indicator, the environmental profile of the GM HT crop has commonly been better than its conventional equivalent;

Where GM HT crops (tolerant to glyphosate) have been widely grown, incidences of weed resistance to glyphosate have occurred (see additional discussion below) and have become a major problem in some regions (see www. weedscience.org). This can be attributed to how glyphosate was originally used with GM HT crops, where because of its highly effective, broad-spectrum post-emergence activity, it was often used as the sole method of weed control. This approach to weed control put tremendous selection pressure on weeds and as a result contributed to the evolution of weed populations dominated by resistant individuals. In addition, the facilitating role of GM HT technology in the adoption of RT/NT production techniques in North and South America has also probably contributed to the emergence of weeds resistant to herbicides like glyphosate and to weed shifts toward those weed species that are not inherently well controlled by glyphosate. As a result, growers of GM HT crops have been and, are increasingly being advised to include other herbicides (with different and complementary modes of action) in combination with glyphosate and in some cases to adopt cultural practices (eg, revert to ploughing) in more integrated weed management systems. At the macro level, these changes have influenced the mix, total amount, cost and overall profile of herbicides applied to GM HT crops in the last $10 \mathrm{y}$. Compared to a decade ago, the amount of herbicide active ingredient applied and number of herbicides used with GM HT crops in many regions has increased, and the associated environmental profile, as measured by the EIQ indicator, deteriorated. This increase in herbicide use relative to several years ago is often cited by anti GM technology proponents (Benbrook, 2012) as an environmental failing of the technology.
However, what such authors fail to acknowledge is that the amount of herbicide used on conventional crops has also increased relative to several years ago and that compared with the conventional alternative, the environmental profile of GM HT crop use has continued to offer important advantages and in most cases, provides an improved environmental profile compared with the conventional alternative (as measured by the EIQ indicator (Brookes et al., 2012)). It should also be noted that many of the herbicides used in conventional production systems had significant resistance issues themselves in the mid 1990s. This was, for example, one of the reasons why glyphosate tolerant soybean technology was rapidly adopted, as glyphosate provided good control of these weeds.

These points are further illustrated in the analysis below which examines changes in herbicide use by crop over the period 1996-2015 and specifically for the latest year examined, 2015.

\section{GM HT Soybean}

The environmental impact of herbicide use change associated with GM HT soybean adoption between 1996 and 2015 is summarised in Table 1. Overall, there has been a small net increase in the amount of herbicide active ingredient used $(+0.5 \%)$, which equates to about 15.3 million $\mathrm{kg}$ more active ingredient applied to these crops than would otherwise have occurred if a conventional crop had been planted. However, the environmental impact, as measured by the EIQ indicator, improved by $13.9 \%$ due to the increased usage of more environmentally benign herbicides.

At the country level, some user countries recorded both a net reduction in the use of herbicide active ingredient and an improvement in the associated environmental impact, as measured by the EIQ indicator. Others, such as Brazil, Bolivia, Paraguay and Uruguay have seen net increases in the amount of herbicide active ingredient applied, though the overall environmental impact, as measured by the EIQ indicator has improved. The largest environmental gains have tended to be in developed countries where the usage of herbicides has traditionally 
TABLE 1. GM HT soybean: Summary of active ingredient usage and associated EIQ changes 1996-2015.

\begin{tabular}{lccc}
\hline & $\begin{array}{c}\text { Change in } \\
\text { active } \\
\text { ingredient use } \\
\text { (million kg) }\end{array}$ & $\begin{array}{c}\text { \% change in } \\
\text { amount of } \\
\text { active } \\
\text { ingredient used }\end{array}$ & $\begin{array}{c}\text { \% change } \\
\text { in EIQ }\end{array}$ \\
indicator
\end{tabular}

Notes: Negative sign $=$ reduction in usage or EIQ improvement. Positive sign $=$ increase in usage or worse EIQ value

been highest and where there has been a significant movement away from the use of several selective herbicides to one broad spectrum herbicide initially, and in the last few years, plus complementary herbicides, with different modes of action, targeted at weeds that are difficult to control with glyphosate.

In 2015, the amount of herbicide active ingredient applied to the global GM HT soybean crop increased by 9.8 million $\mathrm{kg}(+4 \%)$ relative to the amount reasonably expected if this crop area had been planted to conventional cultivars. This highlights the point above relating to recent increases in herbicide use with GM HT crops to take account of weed resistance issues. However, despite these increases in the volume of active ingredient used, in EIQ terms, the environmental impact of the 2015 GM HT soybean crop continued to represent an improvement relative to the conventional alternative (a 10.9\% improvement).

\section{GM HT Maize}

The adoption of GM HT maize has resulted in a significant reduction in the volume of
TABLE 2. GM HT maize: Summary of active ingredient usage and associated EIQ changes 1996-2015.

\begin{tabular}{|c|c|c|c|}
\hline Country & $\begin{array}{l}\text { Change in } \\
\text { active } \\
\text { ingredient use } \\
\text { (million kg) }\end{array}$ & $\begin{array}{l}\text { \% change in } \\
\text { amount of } \\
\text { active } \\
\text { ingredient used }\end{array}$ & $\begin{array}{l}\text { \% change } \\
\text { in EIQ } \\
\text { indicator }\end{array}$ \\
\hline & & & \\
\hline anada & -1 & & \\
\hline entina & -0.6 & - & -6.7 \\
\hline th Africa & -2.7 & -2.5 & -6.8 \\
\hline razil & -8.1 & -2.6 & -8.9 \\
\hline Uruguay & -0.02 & -0.2 & -9.3 \\
\hline $\begin{array}{l}\text { Aggregate } \\
\text { impact: all } \\
\text { countries }\end{array}$ & -226.3 & -8.4 & -12.7 \\
\hline \multicolumn{4}{|l|}{ Notes: } \\
\hline \multicolumn{4}{|c|}{$\begin{array}{l}\text { 1. Negative sign }=\text { reduction in usage or EIQ improvement. Positive } \\
\text { sign = increase in usage or worse EIQ value }\end{array}$} \\
\hline \multicolumn{4}{|c|}{$\begin{array}{l}\text { 2. Other countries using GM HT maize - Colombia, Paraguay and } \\
\text { the Philippines, not included due to lack of data. Also, hand weeding } \\
\text { is likely to be an important form of weed control in the Philippines } \\
\text { suggesting any reduction in herbicide use with GM HT maize has } \\
\text { been limited }\end{array}$} \\
\hline
\end{tabular}

herbicide active ingredient usage and an improvement in the associated environmental impact, as measured by the EIQ indicator, between 1996 and 2015 (Table 2).

In 2015, the reduction in herbicide usage relative to the amount reasonably expected if this crop area had been planted to conventional cultivars was 12.6 million $\mathrm{kg}$ of active ingredient $(-6.2 \%)$, with a larger environmental improvement, as measured by the EIQ indicator of $12.7 \%$. As with GM HT soybeans, the greatest environmental gains have been in developed countries (eg, the US and Canada), where the usage of herbicides has traditionally been highest.

\section{GM HT Cotton}

The use of GM HT cotton delivered a net reduction in herbicide active ingredient use of about 25 million kg over the 1996-2015 period (Table 3). This represents a 7.6\% reduction in usage, and, in terms of the EIQ indicator, a $10.2 \%$ net environmental improvement. In 2015, the use of GM HT cotton technology cotton resulted in a 2 million $\mathrm{kg}$ reduction in herbicide active ingredient use $(-11.2 \%)$ relative 
TABLE 3. GM HT cotton: Summary of active ingredient usage and associated EIQ changes 1996-2015.

\begin{tabular}{lccc}
\hline & $\begin{array}{c}\text { Change in } \\
\text { active } \\
\text { ingredient use } \\
\text { (million kg) }\end{array}$ & $\begin{array}{c}\text { \% change in } \\
\text { amount of } \\
\text { active } \\
\text { ingredient used }\end{array}$ & $\begin{array}{c}\text { \% change } \\
\text { in EIQ }\end{array}$ \\
indicator \\
\hline US & -17.14 & -5.9 & -8.1 \\
South Africa & +0.01 & +1.0 & -7.7 \\
Australia & -2.94 & -15.5 & -20.9 \\
Argentina & -5.0 & -27.6 & -30.7 \\
$\begin{array}{l}\text { Aggregate } \\
\text { impact: all } \\
\text { countries }\end{array}$ & $-\mathbf{2 5 . 0 7}$ & $-\mathbf{7 . 6}$ & $-\mathbf{1 0 . 2}$ \\
\hline
\end{tabular}

Notes:

1. Negative sign $=$ reduction in usage or EIQ improvement. Positive sign $=$ increase in usage or worse EIQ value

2. Other countries using GM HT cotton - Brazil, Colombia and Mexico, not included due to lack of data

to the amount reasonably expected if this crop area had been planted to conventional cotton. In terms of the EIQ indicator, this represents a $12.9 \%$ environmental improvement.

\section{Other HT Crops}

GM HT canola (tolerant to glyphosate or glufosinate) has been grown in Canada, the US, and more recently Australia. GM HT sugar beet is grown in the US and Canada. The environmental impacts associated with changes in herbicide usage on these crops in the period 1996-2015 are summarised in Table 4. GM HT canola use has resulted in a significant reduction in the amount of herbicide active ingredient used relative to the amount reasonably expected if this crop area had been planted to conventional canola. Its use has also resulted in a net environmental improvement of $29.9 \%$, as measured by the EIQ indicator.

In respect of GM HT sugar beet, the adoption of GM HT technology has resulted in a change in herbicide usage away from several applications of selective herbicides to fewer applications of, typically, a single herbicide (glyphosate). Over the period 2008-2015, the widespread use of GM HT technology in the US and Canadian sugar beet crops has resulted
TABLE 4. Other GM HT crops: Summary of active ingredient usage and associated EIQ changes 1996-2015.

\begin{tabular}{lccc}
\hline & $\begin{array}{c}\text { Change in } \\
\text { active } \\
\text { ingredient } \\
\text { use (million } \\
\mathrm{kg})\end{array}$ & $\begin{array}{c}\text { \% change in } \\
\text { amount of } \\
\text { active } \\
\text { ingredient } \\
\text { used }\end{array}$ & $\begin{array}{c}\% \text { change } \\
\text { in EIQ } \\
\text { indicator }\end{array}$ \\
Country & & & \\
\hline GM HT canola & -3.1 & -33.5 & -46.5 \\
US & -21.1 & -19.8 & -32.4 \\
Canada & -0.8 & -3.5 & -3.0 \\
Australia & -25 & -18.1 & -29.9 \\
$\begin{array}{l}\text { Aggregate impact: } \\
\quad \text { all countries }\end{array}$ & & & \\
$\begin{array}{l}\text { GM HT sugar beet } \\
\text { US and Canada }\end{array}$ & +1.8 & +25 & -0.9 \\
\hline
\end{tabular}

Notes:

1. Negative sign $=$ reduction in usage or EIQ improvement. Positive sign $=$ increase in usage or worse EIQ value

2. In Australia, one of the most popular type of production has been canola tolerant to the triazine group of herbicides (tolerance derived from non GM techniques). It is relative to this form of canola that the main farm income benefits of GM HT (to glyphosate) canola has occurred

3. InVigor' hybrid vigour canola (tolerant to the herbicide glufosinate) is higher yielding than conventional or other GM HT canola and derives this additional vigour from GM techniques

4. GM HT alfalfa is also grown in the US. The changes in herbicide use and associated environmental impacts from use of this technology is not included due to a lack of available data on herbicide use in alfalfa

in a net increase in the total volume of herbicides applied to the sugar beet crop relative to the amount reasonably expected if this crop area had been planted to conventional sugar beet (Table 4). The net impact on the environment, as measured by the EIQ indicator has been largely neutral (a marginal improvement in the EIQ value).

In 2015, the use of GM HT canola resulted in a 3 million $\mathrm{kg}$ reduction in the amount of herbicide active ingredient use $(-24 \%)$ relative to the amount reasonably expected if this crop area had been planted to conventional canola. More significantly, there was an improvement in associated environmental impact, as measured by the EIQ indicator of $36 \%$. The use of GM HT technology resulted in a net additional 0.25 million $\mathrm{kg}$ of herbicide active ingredient being applied to the sugar beet crops in the US and Canada $(+28 \%)$ relative to the amount reasonably expected if this crop area had been 
planted to conventional sugar beet. This also resulted in a net deterioration in the associated environmental impact $(+8.8 \%)$ as measured by the EIQ indicator.

\section{Weed Resistance}

As indicated above, weed resistance to glyphosate has become a major issue affecting some farmers using GM HT (tolerant to glyphosate) crops. Worldwide there are currently (accessed March 2017) 37 weeds species resistant to glyphosate of which many are not associated with glyphosate tolerant crops (www. weedscience.org). In the US, there are currently 16 weeds recognized as exhibiting resistance to glyphosate, of which 2 are not associated with glyphosate tolerant crops. In addition, some of the first glyphosate resistant weeds developed in Australia in the mid-1990s before the adoption of GM HT crops and currently there are 13 weeds exhibiting resistance to glyphosate in Australia, even though the area using GM HT (tolerant to glyphosate) crops in the country is relatively small (about 0.71 million ha in 2015). In Argentina, Brazil and Canada, where GM HT crops are widely grown, the number of weed species exhibiting resistance to glyphosate are respectively 9,8 and 5 . A few of the glyphosate-resistant species, such as marestail (Conyza canadensis), waterhemp (Amaranthus tuberculatus) and palmer pigweed (Amaranthus palmeri) in the US, are now reasonably widespread, with the affected area being possibly within a range of $40-60 \%$ of the total area annually devoted to maize, cotton and soybeans.

This resistance development should, however, be placed in context. All weeds have the ability to develop resistance to all herbicides and there are hundreds of resistant weed species confirmed in the International Survey of Herbicide Resistant Weeds (www.weedscience.org), and reports of herbicide resistant weeds pre-date the use of GM HT crops by decades. There are, for example, 159 weed species that are resistant to ALS herbicides (eg, imazethapyr, cloransulam) and 74 weed species resistant to photosystem II inhibitor herbicides (eg, atrazine).
Where farmers are faced with the existence of weeds resistant to glyphosate in GM HT crops, they are increasingly being advised to be more proactive and include other herbicides (with different and complementary modes of action) in combination with glyphosate and in some cases to adopt cultural practices such as ploughing in their integrated weed management systems. This change in weed management emphasis also reflects the broader agenda of developing strategies across all forms of cropping systems to minimise and slow down the potential for weeds developing resistance to existing technology solutions for their control. At the macro level, these changes have already influenced the mix, total amount, cost and overall profile of herbicides applied to GM HT crops in the last $10 \mathrm{y}$.

For example, in the 2015 US GM HT soybean crop, $80 \%$ of the GM HT soybean crop received an additional herbicide treatment of one of the following (4 most used, after glyphosate) active ingredients 2,4-D (used pre-crop planting), chlorimuron, fomesafen and sulfentrazone (each used primarily after crop planting). This compares with $14 \%$ of the GM HT soybean crop receiving a treatment of one of the next 4 most used herbicide active ingredients (after glyphosate) in 2006. As a result, the average amount of herbicide active ingredient applied to the GM HT soybean crop in the US (per hectare) increased by about $81 \%$ over this period. The increase in non-glyphosate herbicide use is primarily in response to public and private sector weed scientist recommendations to diversify weed management programmes and not to rely on a single herbicide mode of action for total weed management. It is interesting to note that in 2015, glyphosate accounted for a lower share of total active ingredient use on the GM HT crop (67\%) than in 1998 when it accounted for $82 \%$ of total active ingredient use, highlighting that farmers continue to realize value in using glyphosate because of its broad-spectrum activity in addition to using other herbicides in line with integrated weed management advice.

On the small conventional crop, the average amount of herbicide active ingredient applied increased by $84 \%$ over the same period (marginally more than the rate of increase in use on 
the GM HT crop: 2006-2015) reflecting a shift in herbicides used rather than increased dose rates for some herbicides. The increase in the use of herbicides on the conventional soybean crop in the US can also be partly attributed to the on-going development of weed resistance to non-glyphosate herbicides commonly used and highlights that the development of weed resistance to herbicides is a problem faced by all farmers, regardless of production method. It is also interesting to note that since the mid 2000s, the average amount of herbicide active ingredient used on GM HT cotton in the US has increased through a combination of additional usage of glyphosate (about a 30\% increase in usage per hectare) in conjunction with increasing use of other herbicides. All of the GM HT crop area planted to seed tolerant to glyphosate received treatments of glyphosate and at least one of the next 5 most used herbicides (trifluralin, acetochlor, diuron, flumioxazin and paraquat). This compares with 2006, when only three-quarters of the glyphosate tolerant crop received at least one treatment from the next 5 most used herbicides (2 4-D, trifluralin, pyrithiobic, pendimethalin and diuron). In other words, a quarter of the glyphosate tolerant crop used only glyphosate for weed control in 2006 compared with none of the crop relying solely on glyphosate in 2015. This suggests that US cotton farmers are increasingly using additional herbicides with different modes of action for managing weed resistance (to glyphosate).

Relative to the conventional alternative, the environmental profile of GM HT crop use has, nevertheless, continued to offer important advantages and in most cases, provides an improved environmental profile compared with the conventional alternative (as measured by the EIQ indicator).

\section{GM IR Crops}

The main way in which these technologies have impacted on the environment has been through reduced insecticide use between 1996 and 2015 (Table 5 and Table 6) with the GM IR technology effectively replacing insecticides used to control important crop pests. This is particularly evident in respect of cotton, which traditionally has been a crop on which intensive treatment regimes of insecticides were common place to control bollworm/budworm pests. In maize, the insecticide use savings have been more limited because the pests that the various technology targets tend to be less widespread in maize than budworm/bollworm pests are in cotton. In addition, insecticides were widely considered to have limited effectiveness against some pests in maize crops (eg, stalk borers) because the pests occur where sprays are not effective (eg, inside stalks). As a result of these factors, the proportion of the maize crop in most GM IR user countries that typically received insecticide treatments before the availability of GM IR technology was much lower than the share of the cotton crops receiving insecticide treatments (e.g., in the US, no more than $10 \%$ of the maize crop typically received insecticide treatments targeted at stalk boring pests and about $30-40 \%$ of the crop annually received treatments of rootworm).

TABLE 5. GM IR maize: Summary of active ingredient usage and associated EIQ changes 1996-2015.

\begin{tabular}{|c|c|c|c|}
\hline Country & $\begin{array}{l}\text { Change in } \\
\text { active } \\
\text { ingredient use } \\
\text { (million kg) }\end{array}$ & $\begin{array}{l}\text { \% change in } \\
\text { amount of } \\
\text { active } \\
\text { ingredient used }\end{array}$ & $\begin{array}{l}\text { \% change } \\
\text { in EIQ } \\
\text { indicator }\end{array}$ \\
\hline JS & -65.9 & -47.8 & -50.9 \\
\hline Canada & -0.71 & -92.2 & -65.1 \\
\hline Spain & -0.58 & -36.4 & -20.7 \\
\hline South Africa & -1.8 & -68.1 & -68.1 \\
\hline Brazil & -17.9 & -88.6 & -88.6 \\
\hline Colombia & -0.18 & -66.3 & -66.3 \\
\hline $\begin{array}{l}\text { Aggregate } \\
\text { impact: all } \\
\text { countries }\end{array}$ & -87.1 & -53.3 & -57.7 \\
\hline \multicolumn{4}{|l|}{ Notes: } \\
\hline \multicolumn{4}{|c|}{$\begin{array}{l}\text { 1. Negative sign = reduction in usage or EIQ improvement. Positive } \\
\text { sign = increase in usage or worse EIQ value }\end{array}$} \\
\hline \multicolumn{4}{|c|}{$\begin{array}{l}\text { 2. Other countries using GM IR maize - Argentina, Uruguay, Para- } \\
\text { guay, Honduras and the Philippines, not included due to lack of data } \\
\text { and/or little or no history of using insecticides to control various pests }\end{array}$} \\
\hline \multicolumn{4}{|c|}{$\begin{array}{l}\text { 3. \% change in active ingredient usage and field EIQ values relates } \\
\text { to insecticides typically used to target lepidopteran pests (and root- } \\
\text { worm in the US and Canada) only. Some of these active ingredients } \\
\text { are, however, sometimes used to control to other pests that the GM } \\
\text { IR technology does not target }\end{array}$} \\
\hline
\end{tabular}


TABLE 6. GMIR cotton: Summary of active ingredient usage and associated EIQ changes 1996-2015.

\begin{tabular}{lccc}
\hline & $\begin{array}{c}\text { Change in } \\
\text { active } \\
\text { ingredient use } \\
\text { (million kg) }\end{array}$ & $\begin{array}{c}\text { \% change in } \\
\text { amount of } \\
\text { active } \\
\text { ingredient used }\end{array}$ & $\begin{array}{c}\text { \% change } \\
\text { in EIQ }\end{array}$ \\
indicator \\
\hline US & -19.5 & -24.9 & -19.6 \\
China & -127.4 & -30.7 & -30.5 \\
Australia & -18.3 & -33.4 & -34.5 \\
India & -99.3 & -28.6 & -36.7 \\
Mexico & -1.9 & -13.4 & -13.2 \\
Argentina & -1.3 & -18.1 & -25.7 \\
Brazil & -1.0 & -11.8 & -15.7 \\
Aggregate & $-\mathbf{2 6 8 . 6}$ & -29.1 & $-\mathbf{3 1 . 5}$ \\
$\quad$ impact: all & & & \\
\multicolumn{1}{c}{ countries } & & & \\
\hline
\end{tabular}

Notes:

1. Negative sign $=$ reduction in usage or EIQ improvement. Positive sign = increase in usage or worse EIQ value

2. Other countries using GM IR cotton - Colombia, Burkina Faso, Paraguay, Pakistan and Myanmar not included due to lack of data

3. \% change in active ingredient usage and field EIQ values relates to all insecticides (as bollworm/budworm pests are the main category of cotton pests worldwide). Some of these active ingredients are, however, sometimes used to control to other pests that that the GM IR technology does not target

The global insecticide savings from using GM IR maize and cotton in 2015 were, 7.8 million $\mathrm{kg}(-84 \%$ of insecticides typically targeted at maize stalk boring and rootworm pests) and 19.3 million $\mathrm{kg}(-53 \%$ of all insecticides used on cotton) respectively of active ingredient use relative to the amounts reasonably expected if these crop areas had been planted to conventional maize and cotton. In EIQ indictor terms, the respective environmental improvements in 2015 were $88.3 \%$ associated with insecticide use targeted at maize stalk boring and rootworm pests and 54\% associated with cotton insecticides. Cumulatively since 1996, the gains have been a 87.1 million $\mathrm{kg}$ reduction in maize insecticide active ingredient use and a 268.6 million $\mathrm{kg}$ reduction in cotton insecticide active ingredient use (Table 5 and Table 6).

In 2015, IR soybeans were in their third year of commercial use in South America (mostly Brazil). During this period (2013-2015), the insecticide use (active ingredient) saving relative to the amount reasonably expected if this crop area had been planted to conventional soybeans was 3.6 million $\mathrm{kg}$ ( $1.4 \%$ of total soybean insecticide use), with an associated environmental benefit, as measured by the EIQ indicator saving of $4.3 \%$.

\section{Aggregated (Global Level) Impacts}

At the global level, GM technology has contributed to a significant reduction in the negative environmental impact associated with insecticide and herbicide use on the areas devoted to GM crops. Since 1996, the use of pesticides on the GM crop area has fallen by 618.7 million $\mathrm{kg}$ of active ingredient (an 8.1\% reduction) relative to the amount reasonably expected if this crop area had been planted to conventional crops. The environmental impact associated with herbicide and insecticide use on these crops, as measured by the EIQ indicator, improved by $18.6 \%$. In 2015 , the environmental benefit was equal to a reduction of 37.4 million $\mathrm{kg}$ of pesticide active ingredient use $(-6.1 \%)$, with the environmental impact associated with insecticide and herbicide use on these crops, as measured by the EIQ indicator, improving by $18.5 \%$.

At the country level, US farms have seen the largest environmental benefits, with a 341 million $\mathrm{kg}$ reduction in pesticide active ingredient use ( $55.1 \%$ of the total). This is not surprising given that US farmers were first to make widespread use of GM crop technology, and for several years, the GM adoption levels in all 4 US crops have been in excess of $80 \%$, and insecticide/herbicide use has, in the past been, the primary method of weed and pest control. Important environmental benefits have also occurred in China and India from the adoption of GM IR cotton, with a reduction in insecticide active ingredient use of over 227 million $\mathrm{kg}$ (1996-2015).

\section{Results: Greenhouse Gas Emission Savings}

\section{Reduced Fuel Use}

The fuel savings associated with making fewer spray runs in GM IR crops of maize and cotton (relative to conventional crops) and the switch to 
reduced tillage or no tillage (RT/NT) farming systems facilitated by GM HT crops, have resulted in permanent savings in carbon dioxide emissions. In 2015, this amounted to a saving of 2,819 million $\mathrm{kg}$ of carbon dioxide, arising from reduced fuel use of 1,056 million liters (Table 7). These savings are equivalent to taking 1.25 million cars off the road for one year.

The largest fuel use-related reductions in carbon dioxide emissions have come from the adoption of GM HT technology in soybeans and how it has facilitated a switch to RT/NT production systems with their reduced soil cultivation practices (77\% of total savings 1996-2015). These savings have been greatest in South America.

Over the period 1996 to 2015, the cumulative permanent reduction in fuel use has been about 26,221 million $\mathrm{kg}$ of carbon dioxide, arising from reduced fuel use of 9,823 million liters. In terms of car equivalents, this is equal to taking 11.65 million cars off the road for a year.

\section{Additional Soil Carbon Storage/ Sequestration}

As indicated earlier, the widespread adoption and maintenance of $\mathrm{RT} / \mathrm{NT}$ production systems in North and South America, facilitated by GM HT crops (especially in soybeans) has improved growers' ability to control competing weeds, reducing the need to rely on soil cultivation and seed-bed preparation as means to getting good levels of weed control. As a result, as well as tractor fuel use for tillage being reduced, soil quality has been enhanced and levels of soil erosion cut. In turn, more carbon remains in the soil and this leads to lower GHG emissions.

Based on savings arising from the rapid adoption of RT/NT farming systems in North and South America, an extra 6,513 million kg of soil carbon is estimated to have been sequestered in 2015 (equivalent to 23,900 million $\mathrm{kg}$ of carbon dioxide that has not been released into the global atmosphere). These savings are equivalent to taking 10.6 million cars off the road for one year (Table 8).

The additional amount of soil carbon sequestered since 1996 has been equivalent to 227,208 million tonnes of carbon dioxide that has not been released into the global atmosphere. Readers should note that these estimates are based on fairly conservative assumptions and therefore the true values could be higher. Also, some of the additional soil

TABLE 7. Carbon storage/sequestration from reduced fuel use with GM crops 2015.

\begin{tabular}{lrrr}
\hline & $\begin{array}{c}\text { Fuel saving } \\
\text { (million } \\
\text { liters) }\end{array}$ & $\begin{array}{c}\text { Permanent carbon dioxide } \\
\text { savings arising from reduced fuel } \\
\text { use (million kg of carbon dioxide) }\end{array}$ & $\begin{array}{c}\text { Permanent fuel savings: as average } \\
\text { family car equivalents removed from } \\
\text { the road for a year ('000s) }\end{array}$ \\
\hline US: GM HT soybean & 198 & 528 & 235 \\
Canada: GM HT soybeans & 18 & 47 & 21 \\
Argentina: GM HT soybean & 277 & 739 & 329 \\
Brazil GM HR soybean & 188 & 501 & 223 \\
Bolivia, Paraguay, Uruguay: GM HT & 64 & 170 & 75 \\
$\quad$ soybean & 145 & 387 & 172 \\
US: GM HT maize & 7 & 19 & 8 \\
Canada: GM HT maize & 71 & 191 & 85 \\
Canada: GM HT canola & 13 & 35 & 16 \\
Global GM IR cotton & 31 & 11 & 37 \\
Brazil IR maize & 4 & 108 & 5 \\
Us/Canada/Spain/South Africa: IR & & $\mathbf{2 , 8 1 9}$ & 48 \\
$\quad$ maize & 40 & & $\mathbf{1 , 2 5 4}$ \\
South America: IR soybeans & $\mathbf{1 , 0 5 6}$ & & \\
Total & & & \\
\hline
\end{tabular}

Notes:

1. Assumption: an average family car produces $150 \mathrm{~g}$ of carbon dioxide per $\mathrm{km}$. A car does an average of $15,000 \mathrm{~km} / \mathrm{year}$ and therefore produces $2,250 \mathrm{~kg}$ of carbon dioxide/year

2. GM IR cotton. Burkina Faso, India, Pakistan, Myanmar and China excluded because insecticides assumed to be applied by hand, using back pack sprayers 
carbon sequestration gains from RT/NT systems may be lost if subsequent ploughing of the land occurs.

Estimating the possible losses that may arise from subsequent ploughing would be complex and difficult to undertake. This factor should be taken into account when using the estimates presented in this paper. It should also be noted that this soil carbon saving is based on savings arising from the rapid adoption of RT/NT farming systems, for which the availability of GM HT technology, has been cited by many farmers as an important facilitator. GM HT technology has therefore probably been an important contributor to this increase in soil carbon sequestration, but is not the only factor of influence. Other influences such as the availability of relatively cheap generic glyphosate (the real price of glyphosate fell threefold between 1995 and 2000 once patent protection for the product expired) have also been important.

Cumulatively, the amount of carbon sequestered may be higher than these estimates due to year-on-year benefits to soil quality (e.g., less soil erosion, greater water retention and reduced levels of nutrient run off). However, it is equally likely that the total cumulative soil sequestration gains have been lower because only a proportion of the crop area will have remained in NT/RT.
It is, nevertheless, not possible to confidently estimate cumulative soil sequestration gains that take into account reversions to conventional tillage because of a lack of data. Consequently, the estimate provided of 227,208 million $\mathrm{kg}$ of carbon dioxide not released into the atmosphere should be treated with caution.

Aggregating the carbon sequestration benefits from reduced fuel use and additional soil carbon storage, the total carbon dioxide savings in 2015 are equal to about 26,719 million $\mathrm{kg}$, equivalent to taking 11.88 million cars off the road for a year. This is equal to $41 \%$ of registered cars in the UK.

\section{Conclusions}

During the last 20 years, the adoption of crop biotechnology by many farmers (18 million in 2015) has delivered important, positive environmental contributions through its facilitation and evolution of environmentally friendly farming practices. More specifically:

- The environmental gains from the GM IR traits have mostly derived from decreased use of insecticides;

- The gains from GM HT traits have come from a combination of effects. In terms of

TABLE 8. Context of carbon sequestration impact 2015: Car equivalents.

\begin{tabular}{lccc}
\hline & $\begin{array}{c}\text { Additional carbon } \\
\text { stored in soil } \\
\text { (million kg of } \\
\text { carbon) }\end{array}$ & $\begin{array}{c}\text { Potential additional soil } \\
\text { carbon sequestration } \\
\text { savings (million kg of } \\
\text { carbon dioxide) }\end{array}$ & $\begin{array}{c}\text { Soil carbon sequestration } \\
\text { savings: as average family car } \\
\text { equivalents removed from the } \\
\text { road for a year ('000s) }\end{array}$ \\
\hline US: GM HT soybean & 774 & 2,840 & 1,262 \\
Canada: GM HT soybeans & 67 & 247 & 110 \\
Argentina: GM HT soybean & 2,043 & 7,496 & 3,332 \\
Brazil GM HR soybean & 1,385 & 5,082 & 2,259 \\
Bolivia, Paraguay, Uruguay: GM HT soybean & 469 & 1,722 & 765 \\
US: GM HT maize & 1,497 & 5,495 & 2,442 \\
Canada: GM HT maize & 15 & 54 & 24 \\
Canada: GM HTcanola & 263 & 964 & 428 \\
Global GM IR cotton & 0 & 0 & 0 \\
Brazil IR maize & 0 & 0 & 0 \\
Us/Canada/Spain/South Africa: IR maize & 0 & 0 & 0 \\
South America: IR soybeans (included in HT & 0 & $\mathbf{2 3 , 9 0 0}$ & 0 \\
$\quad$ soybeans above) & $\mathbf{6 , 5 1 3}$ & 0 & $\mathbf{1 0 , 6 2 2}$ \\
Total & & & 0 \\
\hline
\end{tabular}


the environmental impact associated with herbicide use, important changes in the profile of herbicides used have occurred, in favor of more environmentally benign products. Secondly, the technology has facilitated changes in farming systems, by enabling farmers to BETTER capitalise on the availability of a low cost, broad-spectrum herbicide (glyphosate) and move away from conventional to RT/NT production systems in both North and South America. This change in production system has reduced levels of GHG emissions from reduced tractor fuel use and additional soil carbon sequestration.

In relation to GM HT crops, however, over reliance on the use of glyphosate by farmers, in some regions, has contributed to the development of weed resistance. As a result, farmers have over the last 10 years, adopted more integrated weed management strategies incorporating a mix of herbicides. As a result, the magnitude of the original environmental gains associated with changes in herbicide use with GM HT crops have diminished. Despite this, the adoption of GM HT crop technology continues to deliver a net environmental gain relative to the conventional alternative and, together with GM IR technology, continues to provide substantial net environmental benefits. These findings are also consistent with analysis by other authors. (Klumper \& Qaim, 2014, Fernandez-Cornejo J, et al, 2014)

\section{Methodology}

The available literature examining the environmental impact of pesticide use change and implications for greenhouse gas emissions associated with the adoption of GM crops is more limited than the literature examining the economic impacts associated with use of the technology.

This analysis draws on a combination of this literature and a significant amount of 'authors' own analysis' of farm level changes in husbandry practices and pesticide usage data. In particular, readers should note that the analysis of the environmental impact of pesticide usage changes with GM crops includes consideration of measures taken by farmers to address issues of weed resistance to the main herbicide (glyphosate) used with GM HT crops.

\section{Methodology: Environmental Impacts from Insecticide and Herbicide Use Changes}

Assessment of the impact of GM crops on insecticide and herbicide use requires comparisons of the respective weed and pest control measures used on GM versus the 'conventional alternative' form of production. This presents several challenges relating to availability and representativeness.

Comparison data ideally derives from farm level surveys which collect usage data on the different forms of production. A search of the literature on insecticide or herbicide use change with GM crops shows that the number of studies exploring these issues is limited )Qaim M, 2005, Qaim M, 2002, Pray C, 2002) with even fewer (Brookes, 2003). (Brookes, 2005), providing data to the pesticide (active ingredient) level. Secondly, national level pesticide usage survey data are also extremely limited; in fact there are no published, detailed, annual pesticide usage surveys conducted by national authorities in any of the countries currently growing GM crop traits and, the only country in which pesticide usage data are collected (by private market research companies) on an annual basis, and which allows a comparison between GM and conventional crops to be made, is the US. The US Department of Agriculture also conducts pesticide usage surveys but these are not conducted on an annual basis (eg, the last time maize was included was 2014 and previous to this, in 2010 and 2005, for soybeans the last time included was 2015 and before that, 2012) and do not disaggregate usage by production type (GM vs. conventional).

Even where national pesticide use survey data are available, it is often of limited value. A reasonable estimate of the amount of herbicide or insecticide usage changes that have occurred with GM crop technology, requires an 
assessment of what herbicides/insecticides might reasonably be expected to be used in the absence of crop biotechnology on the relevant crops (ie, if the entire crops used non GM production methods). Applying usage rates for the current (remaining) conventional crops is one approach, however, this invariably provides significant under estimates of what usage might reasonably be in the absence of crop biotechnology, because the conventional cropping data set used to identify pesticide use relates to a relatively small share of total crop area. This has been the case, for example, in respect of the US maize, canola, cotton and soybean crops for many years. Thus in 2015, the conventional share (not using GM HT technology) of each crop was only $6 \%, 7 \%, 6 \%$ and $7 \%$ respectively for soybean, maize, cotton and canola, with the conventional share having been below $50 \%$ of the total since 1999 in respect of the soybean crop, since 2001 for the cotton and canola crops, and since 2007 for the maize crop (source: USDA - note the conventional share refers to not using GM HT technology, with some of the 'conventional crops' using crop biotechnology-traited seed providing GM insect resistance only).

The reasons why this conventional cropping data set is unrepresentative of the levels of herbicide/insecticide use that might reasonably be expected in the absence of biotechnology include:

- Although the degree of pest/weed problems/damage vary by year, region and within region, farmers' who continue to farm conventionally may be those with relatively low levels of pest/weed problems, and hence see little, if any economic benefit from using the GM traits targeted at minimal pest/weed problems. In addition, late or non adopters of new technology in agriculture are typically those who generally make less use of newer technologies than earlier adopters. As a result, insecticide/herbicide usage levels for these non adopting farmers tends to be below the levels that would reasonably be expected on an average farm with more typical pest/weed infestations and where farmers are more willing to adopt new technology;

- Some of the farms continuing to use conventional seed generally use extensive, low intensity production methods (including organic) which feature, limited (below average) use of herbicides/insecticides. The usage patterns of this sub-set of growers is therefore likely to understate usage for the majority of farmers if they all returned to farming without the use of GM technology;

- The widespread adoption of GM IR technology has resulted in 'area-wide' suppression of target pests in maize and cotton crops. As a result, conventional farmers (eg, of maize in the US) have benefited from this lower level of pest infestation and the associated reduced need to apply insecticides. (Hutchison et al., 2010)

- Some of the farmers using GM traits have experienced improvements in pest/weed control from using this technology relative to the conventional control methods previously used. If these farmers were to now switch back to using conventional techniques, it is likely that most would wish to maintain the levels of pest/weed control delivered with use of the GM traits and therefore some would use higher levels of insecticide/herbicide than they did in the pre GM crop days. This argument can, however, be countered by the constraining influence on farm level pesticide usage that comes from the cost of pesticides and their application. Ultimately the decision to use more pesticide or not would be made at the farm level according to individual assessment of the potential benefits (from higher yields) compared with the cost of additional pesticide use.

This problem of poor representativeness of the small conventional data set has been addressed by first, using the average recorded values for insecticide/herbicide usage on conventional crops for years only when the conventional crop accounted for the majority of the total crop and, second, in other years 
(e.g., from 1999 for soybeans, from 2001 for cotton and from 2007 for maize in the US) applying estimates of the likely usage if the whole US crop was no longer using crop biotechnology, based on opinion from extension and industry advisors across the US as to what farmers might reasonably be expected to use in terms of weed control practices and usage levels of insecticide/herbicide. In addition, the usage levels identified from this methodology were cross checked (and subject to adjustment) against historic average usage levels of key herbicide and insecticide active ingredients from the private market research data set so as to minimise the scope for overstating likely usage levels on the conventional alternative. Overall, this approach has been applied in other countries where pesticide usage data are available, though more commonly, because of the paucity of available data, the analysis relies more on extension/ advisor opinion and knowledge of actual and potential pesticide use.

This methodology has been used by others. (Sankula \& Blumenthal, 2003, Sankula \& Blumenthal, 2006, Johnson \& Strom, 2006) It also has the advantage of providing comparisons of current crop protection practices on both GM crops and the conventional alternatives and so takes into account dynamic changes in crop protection management practices and technologies rather than making comparisons solely on past practices. Details of how this methodology has been applied to the 2015 calculations, sources used for each trait/country combination examined and examples of typical conventional vs. GM pesticide applications are provided in Appendices 1 and 2.

The most common way in which environmental impact associated with pesticide use changes with GM crops has typically been presented in the literature has been in terms of the volume (quantity) of pesticide applied. Although the amount of pesticide applied to a crop is one way of trying to measure the environmental impact of pesticide use, it is not a good measure of environmental impact because the toxicity of each pesticide is not directly related to the amount (weight) applied. For example, the environmental impact of applying a kilogram of dioxin to a crop is far more toxic than applying a kilogram of salt. There exist alternative (and better) measures that have been used by several authors of peer reviewed papers to assess the environmental impact of pesticide use change with GM crops rather than simply looking at changes in the volume of active ingredient applied to crops. In particular, there are several peer reviewed papers that utilize the Environmental Impact Quotient (EIQ) developed at Cornell University by Kovach et al $\left(1992^{24}\right)$ and updated annually. This effectively integrates the various environmental impacts of individual pesticides into a single 'field value per hectare'. The EIQ value is multiplied by the amount of pesticide active ingredient (ai) used per hectare to produce a field EIQ value. For example, the EIQ rating for glyphosate is 15.33 . By using this rating multiplied by the amount of glyphosate used per hectare (eg, a hypothetical example of $1.1 \mathrm{~kg}$ applied per ha), the field EIQ value for glyphosate would be equivalent to $16.86 /$ ha. The EIQ indicator used is therefore a comparison of the field EIQ/ha for conventional vs. GM crop production systems, with the total environmental impact or load of each system, a direct function of respective field EIQ/ha values and the area planted to each type of production (GM vs. conventional). The use of environmental indicators is commonly used by researchers and the EIQ indicator has been, for example, cited by Brimner et al (Brimner et al., 2005) (2004) in a study comparing the environmental impacts of GM and conventional canola and by Kleiter et al (Kleiter, 2005) (2005). The EIQ indicator provides an improved assessment of the impact of GM crops on the environment when compared with only examining changes in volume of active ingredient applied, because it draws on some of the key toxicity and environmental exposure data related to individual products, as applicable to impacts on farm workers, consumers and ecology.

The authors of this analysis have also used the EIQ indicator now for several years because it:

- Summarizes significant amounts of information on pesticide impact into a single 
value that, with data on usage rates (amount of active used per hectare) can be readily used to make comparisons between different production systems across many regions and countries;

- Provides an improved assessment of the impact of GM crops on the environment when compared with only examining changes in volume of active ingredient applied, because it draws on some of the key toxicity and environmental exposure data related to individual products, as applicable to impacts on farm workers, consumers and ecology.

The authors, do, however acknowledge that the EIQ is only a hazard indicator and has important weaknesses (see for example, Peterson and Schleier [2014] and Kniss and Coburn [2015; Kniss, 2015]). It is a hazard rating indicator that does not assess risk or probability of exposure to pesticides. It also relies on qualitative assumptions for the scaling and weighting of (quantitative) risk information that can result, for example, in a low risk rating for one factor (e.g., impact on farm workers) may cancel out a high risk rating factor for another factor (e.g., impact on ecology). Fundamentally, assessing the full environmental impact of pesticide use changes with different production systems is complex and requires an evaluation of risk exposure to pesticides at a site-specific level. This requires substantial collection of (site-specific) data (e.g., on ground water levels, soil structure) and/or the application of standard scenario models for exposure in several locations. Undertaking such an exercise at a global level would require a substantial and ongoing input of labor and time, if comprehensive environmental impact of pesticide change analysis is to be completed. It is not surprising that no such exercise has, to date been undertaken, or likely to be in the near future.

Despite the acknowledged weaknesses of the EIQ as an indictor of pesticide environmental impact, the authors of this paper continue to use the EIQ as an indicator of the environmental impact of pesticide use change with GM crops because it is, in our view, a superior indicator to only using amount of pesticide active ingredient applied. In this paper, the EIQ indicator is used in conjunction with examining changes in the volume of pesticide active ingredient applied.

Detailed examples of the relevant amounts of active ingredient used and their associated field EIQ values for GM vs. conventional crops for the year 2015 are presented in Appendix 2.

\section{Methodology: Impact of Greenhouse Gas Emissions}

The methodology used to assess impact on greenhouse gas emissions combines reviews of literature relating to changes in fuel and tillage systems and carbon emissions, coupled with evidence from the development of relevant GM crops and their impact on both fuel use and tillage systems. Reductions in the level of GHG emissions associated with the adoption of GM crops are acknowledged in a wide body of literature. (Conservation Tillage \& Plant Biotechnology (CTIC) 2002, American Soybean Association Conservation Tillage Study 2001, Fabrizzi et al., 2003, Jasa, 2002, Reicosky, 1995, Robertson et al., 2000, Johnson et al., 2005, Leibig et al., 2005, West \& Post, 2002, Derpsch et al., 2010, Eagle et al., 2012, Olson et al., 2013)

First, GM crops contribute to a reduction in fuel use due to less frequent herbicide or insecticide applications and a reduction in the energy use in soil cultivation. For both herbicide and insecticide spray applications, the quantity of energy required to apply the pesticides depends upon the application method. For example, in the USA, a typical method of application is with a 50 foot boom sprayer which consumes approximately 0.84 liters/ha (Lazarus (2013) (Lazarus WF). In terms of GHG, each liter of tractor diesel consumed contributes an estimated $2.67 \mathrm{~kg}$ of carbon dioxide into the atmosphere (so 1 less spray run reduces carbon dioxide emissions by $2.24 \mathrm{~kg} / \mathrm{ha}$ ). Given that many farmers apply insecticides via sprayers pulled by tractors, which tend to use higher levels of fuel than self-propelled boom sprayers, these estimates for reductions in carbon emissions, which are based on self-propelled boom 
application, probably understate the carbon benefits.

In addition, there has been a shift from conventional tillage $(\mathrm{CT})$ to reduced/no till (RT/ NT). No-till farming means that the ground is not ploughed at all, while reduced tillage means that the ground is disturbed less than it would be with traditional tillage systems. For example, under a no-till farming system, soybean seeds are planted through the organic material that is left over from a previous crop such as corn, cotton or wheat) facilitated by GM HT technology (see for example, CTIC (2002) (Conservation Tillage \& Plant Biotechnology (CTIC) 2002) and American Soybean Association (2001) (American Soybean Association Conservation Tillage Study 2001), especially where soybean growing and/or a soybean: corn rotation are commonplace. Before the introduction of GM HT technology, RT/NT systems were practised by some farmers with varying degrees of success using several herbicides, though in many cases, a reversion to CT was common after a few years due to poor levels of weed control. The availability of GM HT technology provided growers with an opportunity to control weeds in a RT/NT system with a non-residual, broad-spectrum, foliar herbicide as a 'burndown' pre-seeding treatment followed by a post-emergent treatment when the crop became established, in what proved to be a more reliable and commercially attractive system than was previously possible. These technical and cost advantages have contributed to the rapid adoption of GM HT cultivars and RT/NT production systems. For example, there has been a 50\% increase in the RT/NT soybean area in the US and a 7-fold increase in Argentina since 1996. In 2015, RT/NT production accounted for $83 \%$ and $89 \%$ respectively of total soybean production in the US and Argentina, with over $95 \%$ of the RT/NT soybean crop area in both countries using GM HT technology.

Substantial growth in RT/NT production systems have also occurred in Canada, where the proportion of the total canola crop accounted for by RT/NT systems increased from $25 \%$ in 1996 to $50 \%$ by 2004 , and in 2015 , accounted for $75 \%$ of the total crop was planted to GM HT cultivars (80\% the GM HT crop was RT/NT).

This shift away from a plough-based, to a RT/NT production system has resulted in a reduction in fuel use. The fuel savings used in this paper are drawn from a review of literature including Jasa (Jasa, 2002), CTIC (Conservation Tillage \& Plant Biotechnology (CTIC) 2002), University of Illinois (American Soybean Association Conservation Tillage Study 2006), USDA Energy Estimator (USDA Energy Estimator: tillage), Reeder (Reeder, 2010 ) and the USDA Comet-VR model (American Soybean Association Conservation Tillage Study 2013). In the analysis presented below, it is assumed that the adoption of NT farming systems in soybean production reduces cultivation and seedbed preparation fuel usage by 27.12 liters/ha compared with traditional conventional tillage and in the case of RT (mulch till) cultivation by 10.39 liters/ha. In the case of maize, NT results in a saving of 24.41 liters/ha and 7.52 liters/ha in the case of RT compared with conventional intensive tillage. These are conservative estimates and are in line with the USDA Energy Estimator for soybeans and maize.

The adoption of NT and RT systems in respect of fuel use therefore results in reductions of carbon dioxide emissions of $72.41 \mathrm{~kg} /$ ha and $27.74 \mathrm{~kg} / \mathrm{ha}$ respectively for soybeans and $65.17 \mathrm{~kg} / \mathrm{ha}$ and $20.08 \mathrm{~kg} / \mathrm{ha}$ for maize.

Secondly, the use of RT/NT farming systems increases the amount of organic carbon in the form of crop residue that is stored or sequestered in the soil and therefore reduces carbon dioxide emissions to the environment. A number of researchers have examined the relationship between carbon sequestration and different tillage systems. (Intergovernmental Panel on Climate Change 2006, Robertson et al., 2000, Johnson et al., 2005, Leibig et al., 2005, Calegari et al., 2000, Baker et al., 2007, Angers \& Eriksen-Hamel, 2008, Blanco-Canqui \& Lal, 2008, Lal, 2004, Lal, 2005, Lal, 2010, Bernacchi et al., 2005, Michigan State University 2016, Wutzler \& Reichstein, 2006). This literature shows that the amount of carbon sequestered varies by soil type, cropping system, eco-region and tillage depth. It also shows 
that tillage systems can impact on levels of other GHG emissions such as methane and nitrous oxide and on crop yield.

Overall, the literature highlights the difficulty in estimating the contribution NT/RT systems can make to soil carbon sequestration, especially because of the dynamic nature of soils, climate, cropping types and patterns. If a specific crop area is in continuous NT crop rotation, the full soil carbon sequestration benefits described in the literature can be realized. However, if the NT crop area is returned to a conventional tillage system, a proportion of the soil organic carbon gain will be lost. The temporary nature of this form of carbon storage only becomes permanent when farmers adopt a continuous NT system, which as indicated earlier, is highly dependent upon having an effective herbicide-based weed control system.

Estimating long-term soil carbon sequestration is also further complicated by the hypothesis typically used in soil carbon models that the level of soil organic carbon (SOC) reaches an equilibrium when the amount of carbon stored in the soil equals the amount of carbon released (the Carbon-Stock Equilibrium (CSE)). This implies that as equilibrium is reached the rate of soil carbon sequestration may decline and therefore if equilibrium is being reached after many years of land being in NT, the rate of carbon sequestration in GM HT may be declining. Our estimates presented in this paper, however, assume that a constant rate of carbon sequestration occurs because of the relatively short time period that NT/RT production systems have been operated (and hence the time period that land may have been in "permanent non-cultivation is a maximum of 15-20 years). In addition, some researchers question whether the CSE assumption that is used in most soil models is valid because of the scope for very old soils to continue to store carbon. (Lal, 2004)

Drawing on the literature and models referred to above, the analysis presented in the following sub-sections assumes the following:

US: The soil carbon sequestered by tillage system for corn in continuous rotation with soybeans is assumed to be a net sink of $250 \mathrm{~kg}$ of carbon/ha/year based on:
- NT systems store $251 \mathrm{~kg}$ of carbon/ha/ year;

- RT systems store $75 \mathrm{~kg}$ of carbon/ha/year;

- CT systems store $1 \mathrm{~kg}$ of carbon/ha/year.

The soil carbon sequestered by tillage system for soybeans in a continuous rotation with corn is assumed to be a net sink of $100 \mathrm{~kg}$ of carbon/ha/year based on:

- NT systems release $45 \mathrm{~kg}$ of carbon/ha/ year;

- RT systems release $115 \mathrm{~kg}$ of carbon/ha/ year;

- CT systems release $145 \mathrm{~kg}$ of carbon/ha/ year.

Argentina and Brazil: soil carbon retention is $175 \mathrm{~kg}$ carbon/ha/year for NT soybean cropping and CT systems release $25 \mathrm{~kg}$ carbon/ha/year (a difference of $200 \mathrm{~kg}$ carbon/ ha/year). In previous editions of this report the difference used was $300 \mathrm{~kg}$ carbon/ha/ year.

Overall, the GHG emission savings derived from reductions in fuel use for crop spraying have been applied only to the area of GM IR crops worldwide (but excluding countries where conventional spraying has traditionally been by hand, such as in India and China) and the savings associated with reductions in fuel from less soil cultivation plus soil carbon storage have been limited to NT/RT areas in North and South America that have utilised GM HT technology. Lastly, some RT/NT areas have also been excluded where the consensus view is that GM HT technology has not been the primary reason for use of these non plough-based systems (ie, parts of Brazil).

Additional detail relating to the estimates for carbon dioxide savings at the country and trait levels are presented in Appendix 3.

\section{DISCLOSURE OF POTENTIAL CONFLICTS OF INTEREST}

No potential conflicts of interest were disclosed. 


\section{FUNDING}

The authors acknowledge that funding toward the researching of this paper was provided by Monsanto. The material presented in this paper is, however, the independent views of the authors - it is a standard condition for all work undertaken by PG Economics that all reports are independently and objectively compiled without influence from funding sponsors.

\section{ORCID}

Peter Barfoot (D) http://orcid.org/0000-0003-
0081-7275

\section{REFERENCES}

American Soybean Association Conservation Tillage Study. 2001. Available at: https://soygrowers.com/asastudy-confirms-environmental-benefits-of-biotech-soy beans/

Angers DA, Eriksen-Hamel NS. Full-inversion tillage and organic carbon distribution in soil profiles: a metaanalysis. Soil Sci Soc Am J 2008; 72:1370-4; http:// dx.doi.org/10.2136/sssaj2007.0342

Asia-Pacific Consortium on Agricultural Biotechnology (APCoAB). Bt cotton in India: a status report, ICRASTAT, New Delhi, India; 2006. Unpublished.

Baker J, Ochsner T, Venterea T, Griffis T. Tillage and soil carbon sequestration-What do we really know? Agriculture, Ecosystems Environment 2007; 118:1-5; http://dx.doi.org/10.1016/j.agee.2006.05.014

Benbrook C. A review and assessment of impact of genetically engineered crops on pesticide use in the US - the first sixteen years. Environmental Sci Europe 2012; 24:24; http://dx.doi.org/10.1186/2190-4715-24-24

Bernacchi CJ, Hollinger SE, Meyers T. The conversion of the corn/soybean ecosystem to no-till agriculture may result in a carbon sink. Global Change Biol 2005; 11 (11):1867-72; http://dx.doi.org/10.1111/j.1365-2486. 2005.01050

Blanco-Canqui H, Lal R. No-tillage and soil-profile carbon sequestration: an on-farm assessment. Soil Sci Soc Am J 2008; 72:693-701; http://dx.doi.org/ $10.2136 /$ sssaj2007.0233

Brimner T, Gallivan G, Stephenson G. Influence of herbicide-resistant canola on the environmental impact of weed management. Pest Management Science 2005; 61:47-52; PMID:15593073; http://dx.doi.org/10.1002/ ps. 967
Brookes G. The benefits of adopting GM insect resistant (Bt) maize in the EU: first results from 1998-2006. Int J Biotechnol 2008; 10:148-66; http://dx.doi.org/ 10.1504/IJBT.2008.018351

Brookes G. The farm-level impact of herbicide-tolerant soybeans in Romania. AgBioForum 2005; 8(4):23541. Available on the World Wide Web: http://www. agbioforum.org

Brookes G, Barfoot P. Global impact of biotech crops: environmental effects 1996-2008. AgBioforum 2010; 13(1):76-94. Available on the World Wide Web: http://www.agbioforum.org

Brookes G, Barfoot P. Global impact of biotech crops: environmental effects 1996-2009. GM Crops 2011; 2 (1):34-49; PMID:21844697; http://dx.doi.org/10.4161/ gmcr.2.1.15529

Brookes G, Barfoot P. Global impact of biotech crops: environmental effects 1996-2010. GM Crops 2012; 3:129-37; http://dx.doi.org/10.4161/gmcr.20061

Brookes G, Barfoot P. Environmental impacts of GM crop use 1996-2013: impacts on pesticide use and carbon emissions. GM Crops 2015; 6:103-33; http://dx.doi. org/10.1080/21645698.2015.1025193

Brookes G, Barfoot P. Global impact of biotech crops: socio-economic and environmental effects 1996-2004. AgbioForum 2006; 8(2\&3):187-96, Available on the World Wide Web: http://www.agbioforum.org

Brookes G, Barfoot P. Global impact of biotech crops: socio-economic and environmental effects 1996-2005. Agbioforum 2007; 9(3):1-13. Available on the World Wide Web: http://www.agbioforum.org

Brookes G, Barfoot P. Global impact of biotech crops: socio-economic and environmental effects 1996-2006. Agbioforum 2008; 11(1):21-38. Available on the World Wide Web: http://www.agbioforum.org

Brookes G, Barfoot P. Key environmental impacts of global GM crop use 1996-2011. GM Crops 2013; 4:111; http://dx.doi.org/10.4161/gmcr.22748

Brookes G, Barfoot P. Key environmental impacts of GM crops 1996-2012. GM Crops 2014; 5:149-160; http:// dx.doi.org/10.4161/gmcr.28449

Brookes G, Carpenter J, McHughen A. A review and assessment of Impact of genetically engineered crops on pesticide use in the US - the first sixteen years' by Benbrook C. 2012. Available at: www.pgeconomics. co.uk/publications.php

Calegari A, Hargrove W, Rheinheimer D, Ralisch R, Tessier D, De Tourfonnet S, Guimaraes Ml. Impact of Long-Term No-Tillage and Cropping System Management on Soil Organic Carbon in an Oxisil: A Model for Sustainability. Agronomy J 2000; 100:1013-9; http://dx.doi.org/10.2134/agronj2007.0121

Canola Council of Canada. An agronomic \& economic assessment of transgenic canola, Canola Council, Canada. 2001. Available at: http://www.canolacouncil. org/media/504430/17908_transgenic_canola_1.pdf 
Commonwealth Scientific and Industrial Research Organisation (CSIRO). The cotton consultants Australia 2005 Bollgard II comparison report. Collingwood, Australia; 2005.

Conservation Tillage and Plant Biotechnology (CTIC). How new technologies can improve the environment by reducing the need to plough. 2002. Available at http://www.ctic.org/media/pdf/Biotech2003.pdf

Derpsch R, Friedrich T, Kassam A, Hongwen L. Current status of adoption on no-till farming in the world and some of its main benefits. Int J Agric Biol Eng 2010; $3: 1-26$.

Doyle B. The performance of Ingard and Bollgard II cotton in Australia during the 2002/2003 and 2003/2004 seasons. Armidale, Australia: University of N Engl; 2005.

Doyle B. The performance of roundup ready cotton 20012002 in the Australian cotton sector. Armidale, Australia: University N Eng; 2003.

Eagle J, Olander L, Henry L, Haugen-Kozyra K, Millar N, Robertson P. Greenhouse Gas Mitigation potential of agricultural land management in the United States - A synthesis of the literature 2012, Duke University Technical Working Group on Agricultural Greenhouse Gases (T-AGG) Report.

Fabrizzi K, Moron A, Garan F. Soil Carbon and Nitrogen Organic Fractions in Degraded VS Non-Degraded Mollisols in Argentina. Soil Science Society Am J 2003; 67:1831-41; http://dx.doi.org/10.2136/sssaj2003.1831

Fernandez-Cornejo J, Wechsler S, Livingston M, Mitchell L. Genetically engineered crops in the United States. 2014. USDA Economic Research Service report ERR 162. Available at: https://www.ers.usda.gov/webdocs/ publications/err162/43668_err162.pdf

Fisher J, Tozer P. Evaluation of the environmental and economic impact of Roundup Ready Canola in the Western Australian Crop Production System. Curtin University of Technology. 2009. Technical report 11/ 2009. Available at: https://www.abca.com.au/wp-con tent/uploads/2010/01/news_pdf_068_WA_Curtin_Uni versity_canola_study.pdf

Galveo A. Farm survey findings of impact of GM crops in Brazil 2011, Celeres, Brazil 2012. Unpublished.

Galveo A. Farm survey findings of impact of insect resistant cotton in Brazil. Celeres, Brazil 2009 \& 2010. Unpublished.

George Morris Centre. Economic \& environmental impacts of the commercial cultivation of glyphosate tolerant soybeans in Ontario. Guelph, Ontario: Author; 2004. Unpublished.

Gianessi L, Carpenter J. Agricultural biotechnology: Insect control benefits. Washington, DC: NCFAP; 1999.

Hutchison W, Burkness EC, Mitchell PD, Moon RD, Leslie TW, Fleischer SJ, Abrahamson M, Hamilton KL, Steffey KL, Gray ME, et al. Area-wide suppression of European Corn Borer with Bt maize reaps savings to non-bt maize growers. Science 2010; 330:222-
5. www.sciencemag.org; PMID:20929774; http://dx. doi.org/10.1126/science. 1190242

IMRB International. Socio-economic benefits of Bollgard and product satisfaction (in India). Mumbai, India: Author; 2006. Unpublished.

IMRB International. Socio-economic benefits of Bollgard and product satisfaction in India. Mumbai, India: Author; 2007. Unpublished.

Intergovernmental Panel on Climate Change. Chapter 2: Generic Methodologies Applicable to Multiple LandUse Categories. Guidelines for National Greenhouse Gas Inventories Volume 4. Agriculture, Forestry and Other Land Use. 2006. Available on the World Wide Web: http://www.ipcenggip.iges.or.jp/public/2006 gl/ pdf/4_Volume4/V4_02_Ch2_Generic.pdf

Ismael Y, Bennett R, Morse S, Buthelezi T. Bt cotton, pesticides, labour and health: A case study of smallholder farmers in the Makhathini Flats, Republic of South Africa. Outlook on Agriculture 2003; 32(2):123-128.

Jasa P. Conservation Tillage Systems, Extension Engineer, University of Nebraska. 2002.

Johnson J, Reicosky D, Allmarao R, Sauer T, Venterea R, Dell C. Greenhouse gas contributions and mitigation potential of agriculture in the central USA. Soil Tillage Research 2005; 83:73-94; http://dx.doi.org/10.1016/j. still.2005.02.010

Johnson S, Strom S. Quantification of the impacts on US agriculture of biotechnology-derived crops planted in 2006. Washington, DC: National Center for Food and Agricultural Policy (NCFAP). 2007. Available at: www.ncfap.org/special-reports

Kleiter G. The effect of the cultivation of GM crops on the use of pesticides and the impact thereof on the environment, RIKILT, Wageningen, Netherlands: Institute of Food Safety; 2005.

Klumper W, Qaim M. A meta analysis of the impacts of genetically modified crops. Plos One 2014; 9(11): e111629; PMID:25365303; http://dx.doi.org/10.1371/ journal.pone.0111629

Kniss A, Coburn C. Quantitative evaluation of the environmental impact quotient (EIQ) for comparing herbicides. PLOS One 2015; 10(6):e0131200; PMID:26121252; http://dx.doi.org/10.1371/journal.pone.0131200

Kovach J, Petzoldt C, Degni J, Tette J. A method to measure the environmental impact of pesticides. New York's Food and Life Sciences Bulletin. NYS Agriculture. Exp. Sta. Cornell University, Geneva, NY, 139. 8 pp. 1992 and annually updated.

Lal R. Beyond Copenhagen: mitigating climate change and achieving food security through soil carbon sequestration. Food Security 2010; 2(2):169-77; http:// dx.doi.org/10.1007/s12571-010-0060-9

Lal R. Enhancing crop yields in the developing countries through restoration of the soil organic carbon pool in agricultural lands. Land Degradation Dev 2005; 17:197-209; http://dx.doi.org/10.1002/ldr.696 
Lal R. Soil carbon sequestration impacts on global climate change and food security. Science 2004; 304:1623-7; PMID:15192216; http://dx.doi.org/ 10.1126/science. 1097396

Lazarus WF. Machinery cost estimates May 2013, University of Minnesota Extension Service. Available at: http://www.minnesotafarmguide.com/news/regional/ machinery-cost-estimates/pdf_a5a9623c-636a-11e38546-0019bb2963f4.html

Leibig M, Morgan J, Reeder J, Elert B, Gollany H, Schuman G. Greenhouse gas contributions and mitigation potential of agriculture practices in north-western USA and Western Canada. Soil Tillage Res 2005; 83:25-52; http://dx.doi.org/10.1016/j.still.2005.02.008

Michigan State University. US Cropland greenhouse gas calculator. 2016. Available at: http://surf.kbs.msu.edu

Monsanto Brazil. Farm survey of conventional and Bt cotton growers in Brazil 2007. 2008. Unpublished.

Monsanto Comercial Mexico. Official report to Mexican Ministry of Agriculture of the 2005 cotton crop. 2005. Unpublished.

Monsanto Comercial Mexico. Official report to Mexican Ministry of Agriculture of the 2007 cotton crop. 2007. Unpublished.

Monsanto Comercial Mexico. Official report to Mexican Ministry of Agriculture of the 2008 cotton crop. 2008. Unpublished.

Monsanto Comercial Mexico. Official report to Mexican Ministry of Agriculture of the 2009 cotton crop. 2009. Unpublished.

Monsanto Comercial Mexico. Official report to Mexican Ministry of Agriculture of the 2011 cotton crop. 2012. Unpublished.

Monsanto Comercial Mexico. Official report to Mexican Ministry of Agriculture of the 2013 cotton crop. 2013. Unpublished.

Monsanto Comercial Mexico. Official report to Mexican Ministry of Agriculture of the 2015 cotton crop. 2015. Unpublished.

Olson K, Ebelhar S, Lang J. Effects of 24 years of conservation tillage systems on soil organic carbon and soil productivity. Applied Environmental Soil Sci 2013; 2013:10; http://dx.doi.org/10.1155/2013/617504

Peterson R, Schleier J. A probabilistic analysis reveals fundamental limitations with the environmental impact quotient and similar systems for rating pesticides. Peer J 2014; 2:e364; PMID:24795854; http://dx.doi.org/ 10.7717/peerj.364

Pray C, Huang J, Hu R, Roselle S. Five years of Bt cotton in China - the benefits continue. Plant Journal 2002; 31(4):423-30; PMID:12182701; http://dx.doi.org/ 10.1046/j.1365-313X.2002.01401.x

Qaim M, De Janvry A. Bt cotton and pesticide use in Argentina: economic and environmental effects, Environment and Development Economics. 2005; 10:179-200.
Qaim M. Traxler G. Roundup ready soybeans in Argentina: Farm level and welfare effects. Agricultural Economics 2005; 32(1), 73-86; http://dx.doi.org/10.1111/ j.0169-5150.2005.00006

Reeder R. No-till benefits add up with diesel fuel savings. 2010. Available at: http://www.thelandonline.com/ archives/no-till-benefits-add-up-with-diesel-fuel-sav ings/article_035dfdc8-1569-5d9b-8b141d9e60c96871.html

Reicosky D. Conservation tillage and carbon cycling: soil as a source or sink for carbon. USA: University of Davis; 1995.

Robertson G, Paul E, Harwood R. Greenhouse gases in intensive agriculture: contributions of individual gases to the radioactive forces of the atmosphere. Science 2000; 289:1922-125; PMID:10988070; http://dx.doi. org/10.1126/science.289.5486.1922

Sankula S, Blumenthal E. Impacts on US agriculture of biotechnology-derived crops planted in 2003: An update of eleven case studies. Washington, DC: NCFAP; 2003.

Sankula S, Blumenthal E. Impacts on US agriculture of biotechnology-derived crops planted in 2005: An update of eleven case studies. Washington, DC: NCFAP; 2006.

Smyth SJ, Gusta M, Belcher K, Phillips PWB, Castle D. Changes in Herbicide Use Following the Adoption of HR Canola in Western Canada. Weed Technol 2011; 25:492500; http://dx.doi.org/10.1614/WT-D-10-00164.1

Traxler G, Godoy-Avilla S, Falck-Zepeda J, EspinozaArellano J. Transgenic cotton in Mexico: Economic and environmental impacts. Paper presented at the $5^{\text {th }}$ International Conference on Biotechnology, Science and Modern Agriculture: A new industry at the dawn of the century, Ravello, Italy. 2001. Available at: https://www.researchgate.net/publication/ 228584807_Transgenic_Cotton_in_Mexico_Economi c_and_Environmental_Impacts

University of Illinois. Costs and fuel use for alternative tillage systems. 2006. Available at: http://www.farm doc.illinois.edu/manage/newsletters/fefo06_07/ fefo06_07.html

USDA Energy Estimator: tillage. 2014. Available at: http://ecat.sc.egov.usda.gov

USDA. An online tool for estimating carbon storage in agroforestry practices (COMET-VR). 2014. Available at: http://www.cometvr.colostate.edu/

West T, Post W. Soil Organic Carbon Sequestration Rates by Tillage and Crop Rotation: A Global Analysis. Soil Sci Society Am J 2002; 66:930-1046; http://dx.doi. org/10.2136/sssaj2002.1930

Wutzler T, Reichstein M. Soils apart from equilibrium consequences for soil carbon balance modelling. Biogeosciences Discuss 2006; 3:1679-714; http://dx.doi. org/10.5194/bgd-3-1679-2006 


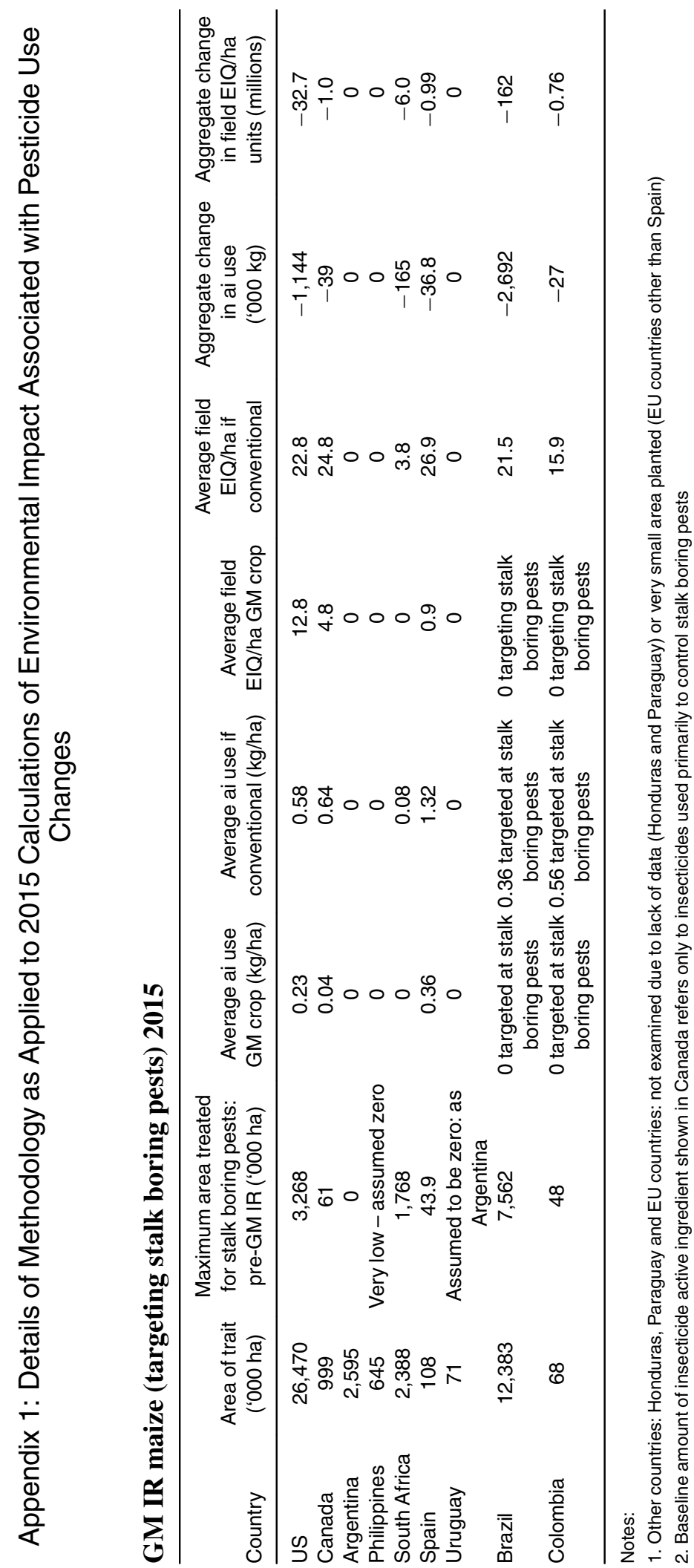




\section{GM IR maize (targeting rootworm) 2015}

\begin{tabular}{ccccccccc}
\hline & $\begin{array}{c}\text { Area of } \\
\text { trait } \\
\text { ('000 ha) }\end{array}$ & $\begin{array}{c}\text { Maximum area } \\
\text { treated for } \\
\text { rootworm pests: pre } \\
\text { GM IR ('000 ha) }\end{array}$ & $\begin{array}{c}\text { Average } \\
\text { ai use GM } \\
\text { crop } \\
(\mathrm{kg} / \mathrm{ha})\end{array}$ & $\begin{array}{c}\text { Average ai } \\
\text { use if } \\
\text { conventional } \\
(\mathrm{kg} / \mathrm{ha})\end{array}$ & $\begin{array}{c}\text { Average } \\
\text { field EIQ/ } \\
\text { ha GM } \\
\text { crop }\end{array}$ & $\begin{array}{c}\text { Average field } \\
\text { EIQ/ha if } \\
\text { conventional }\end{array}$ & $\begin{array}{c}\text { Aggregate } \\
\text { change in ai } \\
\text { use ('000 kg) }\end{array}$ & $\begin{array}{c}\text { Aggregate } \\
\text { EIQ/ha units } \\
\text { (millions) }\end{array}$ \\
\hline US & 15,816 & 9,183 & 0.2 & 0.6 & 12 & 32.5 & $-3,673$ & -188.3 \\
\hline
\end{tabular}

Note:

1. There are no Canadian-specific data available: analysis has therefore not been included for the Canadian crop of 695,000 ha planted to seed containing GM IR traits targeted at rootworm pests

2. The maximum area treated for corn rootworm (on which the insecticide use change is based) is based on the historic area treated with insecticides targeted at the corn rootworm. This is $30 \%$ of the total crop area. The 2015 maximum area on which this calculation is made has been reduced by 620,450 ha to reflect the increased use of soil-based insecticides (relative to usage in a baseline period of 2008-2010) that target the corn rootworm on the GM IR (targeting corn rootworm) area. It is assumed this increase in usage is in response to farmer concerns about the possible development of CRW resistance to the GM IR rootworm technology that has been reported in a small area in the US

\section{GM IR cotton 2015}

\begin{tabular}{|c|c|c|c|c|c|c|c|}
\hline Country & $\begin{array}{l}\text { Area of } \\
\text { trait } \\
\text { ('000 ha) }\end{array}$ & $\begin{array}{l}\text { Average ai } \\
\text { use GM crop } \\
\text { (kg/ha) }\end{array}$ & $\begin{array}{c}\text { Average ai use } \\
\text { if conventional } \\
(\mathrm{kg} / \mathrm{ha})\end{array}$ & $\begin{array}{l}\text { Average field } \\
\text { EIQ/ha GM } \\
\text { crop }\end{array}$ & $\begin{array}{c}\text { Average field } \\
\mathrm{EIQ} / \mathrm{ha} \text { if } \\
\text { conventional }\end{array}$ & $\begin{array}{c}\text { Aggregate } \\
\text { change in ai use } \\
\text { ('000 kg) }\end{array}$ & $\begin{array}{c}\text { Aggregate change } \\
\text { in field EIQ/ha } \\
\text { units (millions) }\end{array}$ \\
\hline US & 2,693 & 0.85 & 1.79 & 27.68 & 47.58 & $-2,533$ & -53.6 \\
\hline China & 2,976 & 2.10 & 2.98 & 87.0 & 106.4 & $-3,780$ & -97.8 \\
\hline Australia & 253 & 0.91 & 2.1 & 25.0 & 65.0 & -301 & -10.1 \\
\hline Mexico & 118 & 3.60 & 5.22 & 120.4 & 177.0 & -192 & -6.7 \\
\hline Argentina & 377 & 0.7 & 2.42 & 19.9 & 76.7 & -123 & -8.7 \\
\hline India & 11,305 & 0.63 & 1.77 & 18.8 & 74.8 & $-12,235$ & -632.8 \\
\hline Brazil & 497 & 0.41 & 0.736 & 15.1 & 38.2 & -155 & -11 \\
\hline
\end{tabular}

Notes:

1. Due to the widespread and regular nature of bollworm and budworm pest problems in cotton crops, GM IR areas planted are assumed to be equal to the area traditionally receiving some form of conventional insecticide treatment

2. South Africa, Burkina Faso, Columbia, Pakistan and Myanmar not included in analysis due to lack of data on insecticide use changes

3. Brazil: due to a lack of data, usage patterns from Argentina have been assumed

\section{GM HT soybean 2015}

\begin{tabular}{lrcccccc}
\hline Country & $\begin{array}{c}\text { Area of } \\
\text { trait } \\
\text { ('000 ha) }\end{array}$ & $\begin{array}{c}\text { Average ai } \\
\text { use GM crop } \\
\text { (kg/ha) }\end{array}$ & $\begin{array}{c}\text { Average ai use } \\
\text { if conventional } \\
\text { (kg/ha) }\end{array}$ & $\begin{array}{c}\text { Average } \\
\text { field EIQ/ha } \\
\text { GM crop }\end{array}$ & $\begin{array}{c}\text { Average field } \\
\text { EIQ/ha if } \\
\text { conventional }\end{array}$ & $\begin{array}{c}\text { Aggregate } \\
\text { change in ai } \\
\text { use ('000 kg) }\end{array}$ & $\begin{array}{c}\text { Aggregate change } \\
\text { in field EIQ/ha } \\
\text { units (millions) }\end{array}$ \\
\hline US & 31,136 & 2.397 & 2.399 & 40.88 & 47.52 & -75 & -206.8 \\
Canada & 1,861 & 1.32 & 1.43 & 20.9 & 34.2 & -205 & -24.8 \\
Argentina & 19,303 & 3.59 & 3.23 & 55.46 & 55.84 & $+7,000$ & -7.49 \\
Brazil & 31,300 & 2.59 & 2.53 & 40.6 & 47.4 & $+1,932$ & -211.0 \\
Paraguay & 3,196 & 3.57 & 3.3 & 44.43 & 51.84 & +866 & -24.0 \\
South Africa & 478 & 1.08 & 1.46 & 16.6 & 27.11 & -183 & -5.0 \\
Uruguay & 1,000 & 2.98 & 2.82 & 47.5 & 48.7 & +163 & -1.2 \\
Bolivia & 1,024 & 3.18 & 3.03 & 50.6 & 51.8 & +277 & -7.6 \\
Mexico & 18 & 1.62 & 1.76 & 24.8 & 41.0 & -3 & -0.3 \\
\hline
\end{tabular}

Notes: Due to lack of country-specific data, usage patterns in Paraguay assumed for Bolivia and usage patterns in Argentina assumed for Uruguay. Industry sources confirm this assumption reasonably reflects typical usage 
GM IR (Intacta) soybeans 2015

\begin{tabular}{lccccccc}
\hline & $\begin{array}{c}\text { Area of } \\
\text { trait } \\
\text { ('000 ha) }\end{array}$ & $\begin{array}{c}\text { Average ai } \\
\text { use GM crop } \\
\text { (kg/ha) }\end{array}$ & $\begin{array}{c}\text { Average ai use if } \\
\text { conventional } \\
\text { (kg/ha) }\end{array}$ & $\begin{array}{c}\text { Average field } \\
\text { EIQ/ha GM } \\
\text { crop }\end{array}$ & $\begin{array}{c}\text { Average field } \\
\text { EIQ/ha if } \\
\text { conventional }\end{array}$ & $\begin{array}{c}\text { Aggregate } \\
\text { change in ai use in field EIQ/ha units } \\
\text { ('000 kg) }\end{array}$ & $\begin{array}{c}\text { Aggregate change } \\
\text { (millions) }\end{array}$ \\
\hline Brazil & 11,800 & 1.43 & 1.6 & 30.65 & 47.9 & $-2,035$ & -203.6 \\
Paraguay & 200 & 1.43 & 1.6 & 30.65 & 47.9 & -16 & -0.25 \\
Argentina & 700 & 0.23 & 0.31 & 7.74 & 9.0 & -56 & -0.9 \\
Uruguay & 200 & 0.23 & 0.31 & 7.74 & 9.0 & -16 & -0.3 \\
\hline
\end{tabular}

\section{GM HT maize 2015}

\begin{tabular}{|c|c|c|c|c|c|c|c|}
\hline Country & $\begin{array}{c}\text { Area of } \\
\text { trait } \\
\text { ('000 ha) }\end{array}$ & $\begin{array}{l}\text { Average ai } \\
\text { use GM crop } \\
\text { (kg/ha) }\end{array}$ & $\begin{array}{l}\text { Average ai use if } \\
\text { conventional } \\
(\mathrm{kg} / \mathrm{ha})\end{array}$ & $\begin{array}{l}\text { Average } \\
\text { field EIQ/ha } \\
\text { GM crop }\end{array}$ & $\begin{array}{c}\text { Average field } \\
\mathrm{EIQ} / \text { ha if } \\
\text { conventional }\end{array}$ & $\begin{array}{c}\text { Aggregate } \\
\text { change in ai } \\
\text { use ('000 kg) }\end{array}$ & $\begin{array}{c}\text { Aggregate change } \\
\text { in field EIQ/ha } \\
\text { units (millions) }\end{array}$ \\
\hline US & 29,084 & 3.02 & 3.41 & 57.36 & 67.36 & $-11,270$ & -290.8 \\
\hline $\begin{array}{l}\text { Canada glyphosate } \\
\text { tolerant }\end{array}$ & 1,260 & 1.83 & 2.71 & 37.0 & 61.1 & $-1,109$ & -30.5 \\
\hline $\begin{array}{l}\text { Canada glufosinate } \\
\text { tolerant }\end{array}$ & 13 & 1.64 & 2.71 & 36.0 & 61.0 & -14 & -0.3 \\
\hline Argentina & 2,238 & 3.99 & 3.53 & 71.8 & 73.6 & $+1,038$ & -4.0 \\
\hline South Africa & 1,647 & 2.85 & 3.15 & 53.7 & 66.1 & -494 & -20.5 \\
\hline Brazil & 9,941 & 3.91 & 3.99 & 70.3 & 86.1 & -815 & -158 \\
\hline Uruguay & 71 & 3.99 & 3.53 & 71.8 & 73.6 & +33 & -0.13 \\
\hline
\end{tabular}

Notes:

1. Philippines: not included due to lack of data on weed control methods and herbicide product use

2. Uruguay - based on Argentine data - industry sources confirm herbicide use in Uruguay is very similar

\section{GM HT cotton 2015}

\begin{tabular}{lccccccc}
\hline & $\begin{array}{c}\text { Area of } \\
\text { trait } \\
\text { ('000 ha) }\end{array}$ & $\begin{array}{c}\text { Average ai } \\
\text { use GM crop } \\
\text { (kg/ha) }\end{array}$ & $\begin{array}{c}\text { Average ai use } \\
\text { if conventional } \\
\text { (kg/ha) }\end{array}$ & $\begin{array}{c}\text { Average field } \\
\text { EIQ/ha GM } \\
\text { crop }\end{array}$ & $\begin{array}{c}\text { Average field } \\
\text { EIQ/ha if } \\
\text { conventional }\end{array}$ & $\begin{array}{c}\text { Aggregate } \\
\text { change in ai } \\
\text { use ('000 kg) }\end{array}$ & $\begin{array}{c}\text { Aggregate change in } \\
\text { field EIQ/ha units } \\
\text { (millions) }\end{array}$ \\
\hline US & 3,142 & 4.42 & 4.82 & 80.74 & 89.03 & $-1,148$ & -23.6 \\
S Africa & 9 & 1.80 & 1.81 & 27.6 & 31.9 & -0.1 & -0.04 \\
Australia & 230 & 5.26 & 7.47 & 90.22 & 143.4 & -595 & -14.4 \\
Argentina & 410 & 4.06 & 4.72 & 64.0 & 78.4 & -269 & -5.9 \\
\hline
\end{tabular}

Notes:

1. Mexico and Colombia: not included due to lack of data on herbicide use

\section{GM HT canola 2015}

\begin{tabular}{lccccccc}
\hline & $\begin{array}{c}\text { Area of } \\
\text { trait } \\
\text { ('000 ha) }\end{array}$ & $\begin{array}{c}\text { Average ai } \\
\text { use GM } \\
\text { crop } \\
(\mathrm{kg} / \mathrm{ha})\end{array}$ & $\begin{array}{c}\text { Average ai use } \\
\text { if conventional } \\
(\mathrm{kg} / \mathrm{ha})\end{array}$ & $\begin{array}{c}\text { Average } \\
\text { field EIQ/ } \\
\text { ha GM } \\
\text { crop }\end{array}$ & $\begin{array}{c}\text { Average field } \\
\text { EIQ/ha if } \\
\text { conventional }\end{array}$ & $\begin{array}{c}\text { Aggregate } \\
\text { change in ai } \\
\text { use ('000 kg) }\end{array}$ & $\begin{array}{c}\text { Aggregate } \\
\text { change in field } \\
\text { EIQ/ha units } \\
\text { (millions) }\end{array}$ \\
\hline Country & 316 & 1.16 & 1.075 & 12.34 & 23.09 & +27 & -1.68 \\
$\begin{array}{l}\text { US glyphosate tolerant } \\
\text { US glufosinate tolerant }\end{array}$ & 329 & 0.425 & 1.075 & 8.6 & 23.09 & -213 & -4.77 \\
$\begin{array}{l}\text { Canada glyphosate } \\
\text { tolerant }\end{array}$ & 3,071 & 1.16 & 1.075 & 12.34 & 23.09 & +264 & -16.3 \\
$\begin{array}{c}\text { Canada glufosinate } \\
\text { tolerant }\end{array}$ & 4,462 & 0.425 & 1.075 & 8.6 & 23.09 & $-2,886$ & -64.6 \\
$\begin{array}{c}\text { Australia glyphosate } \\
\text { tolerant }\end{array}$ & 444 & 0.52 & 14 & 7.3 & 22.3 & -232 & -3.2 \\
\hline
\end{tabular}


GM herbicide tolerant sugar beet 2015

\begin{tabular}{lccccccc}
\hline Country & $\begin{array}{c}\text { Area of } \\
\text { ('000 hait }\end{array}$ & $\begin{array}{c}\text { Average ai use } \\
\text { GM crop } \\
\text { (kg/ha) }\end{array}$ & $\begin{array}{c}\text { Average ai use if } \\
\text { conventional } \\
\text { (kg/ha) }\end{array}$ & $\begin{array}{c}\text { Average field } \\
\text { EIQ/HA } \\
\text { GM crop }\end{array}$ & $\begin{array}{c}\text { Average field } \\
\text { EIQ/ha if } \\
\text { conventional }\end{array}$ & $\begin{array}{c}\text { Aggregate } \\
\text { change in ai } \\
\text { use ('000 kg) }\end{array}$ & $\begin{array}{c}\text { Aggregate } \\
\text { change in field } \\
\text { EIQ/ha units }\end{array}$ \\
\hline US & 454 & 2.61 & 3.16 & 41.03 & 44.14 & -252 & -1.4 \\
\hline
\end{tabular}

Appendix 2: Examples of EIQ Calculations

Estimated typical herbicide regimes for GM HT reduced/no till and conventional reduced/no till soybean production systems that will provide an equal level of weed control to the GM HT system in Argentina 2015

\begin{tabular}{|c|c|c|}
\hline & Active ingredient $(\mathrm{kg} / \mathrm{ha})$ & Field EIQ/ha value \\
\hline GM HT soybean & 3.59 & 55.84 \\
\hline \multicolumn{3}{|l|}{ Source: AMIS Global data set on pesticide use 2015} \\
\hline \multicolumn{3}{|l|}{ Conventional soybean } \\
\hline \multicolumn{3}{|l|}{ Option 1} \\
\hline Glyphosate & 1.92 & 29.43 \\
\hline Metsulfuron & 0.03 & 0.50 \\
\hline $24 \mathrm{D}$ & 0.4 & 8.28 \\
\hline Imazethapyr & 0.10 & 1.96 \\
\hline Diflufenican & 0.03 & 0.29 \\
\hline Clethodim & 0.19 & 3.23 \\
\hline Total & 2.67 & 43.70 \\
\hline \multicolumn{3}{|l|}{ Option 2} \\
\hline Glyphosate & 1.92 & 29.43 \\
\hline Dicamba & 0.12 & 3.04 \\
\hline Acetochlor & 1.35 & 26.87 \\
\hline Haloxifop & 0.18 & 4.00 \\
\hline Sulfentrazone & 0.19 & 2.23 \\
\hline Total & 3.76 & 65.55 \\
\hline \multicolumn{3}{|l|}{ Option 3} \\
\hline Glyphosate & 1.92 & 29.43 \\
\hline Atrazine & 1.07 & 24.50 \\
\hline Bentazon & 0.60 & 11.22 \\
\hline 24 D ester & 0.4 & 6.12 \\
\hline Imazaquin & 0.024 & 0.37 \\
\hline Total & 4.01 & 71.64 \\
\hline \multicolumn{3}{|l|}{ Option 4} \\
\hline Glyphosate & 1.92 & 29.43 \\
\hline 24 D amine & 0.4 & 8.28 \\
\hline Flumetsulam & 0.06 & 0.94 \\
\hline Fomesafen & 0.25 & 6.13 \\
\hline Chlorimuron & 0.05 & 0.96 \\
\hline Fluazifop & 0.12 & 3.44 \\
\hline Total & 2.80 & 49.18 \\
\hline \multicolumn{3}{|l|}{ Option 5} \\
\hline Glyphosate & 1.92 & 29.43 \\
\hline Metsulfuron & 0.03 & 0.50 \\
\hline $24 \mathrm{D}$ amine & 0.8 & 16.56 \\
\hline Imazethapyr & 0.1 & 1.96 \\
\hline Haloxifop & 0.18 & 4.00 \\
\hline Total & 3.03 & 52.45 \\
\hline \multicolumn{3}{|l|}{ Option 6} \\
\hline & & inued on next page) \\
\hline
\end{tabular}


Continued

\begin{tabular}{lcr}
\hline & Active ingredient (kg/ha) & Field EIQ/ha value \\
\hline Glyphosate & 1.92 & 29.43 \\
Metsulfuron & 0.03 & 0.50 \\
2 4 D amine & 0.8 & 16.56 \\
Imazethapyr & 0.1 & 1.96 \\
Clethodim & 0.24 & 4.08 \\
Total & $\mathbf{3 . 0 9}$ & $\mathbf{5 2 . 5 3}$ \\
Average all 6 conventional options & $\mathbf{3 . 2 3}$ & $\mathbf{5 5 . 8 4}$ \\
\hline
\end{tabular}

Sources: AAPRESID, AMIS Global, Monsanto Argentina

\section{Typical insecticide regimes for cotton in India 2015}

\begin{tabular}{|c|c|c|}
\hline Active ingredient & Amount (kg/ha of crop) & Field EIQ/ha \\
\hline \multicolumn{3}{|l|}{ Conventional cotton } \\
\hline \multicolumn{3}{|l|}{ Option 1} \\
\hline Imidacloprid & 0.06 & 2.2 \\
\hline Thiomethoxam & 0.05 & 1.67 \\
\hline Acetamiprid & 0.05 & 1.45 \\
\hline Diafenthiuron & 0.1 & 2.53 \\
\hline Buprofezin & 0.07 & 2.55 \\
\hline Profenfos & 0.81 & 48.28 \\
\hline Acephate & 0.63 & 15.79 \\
\hline Cypermethrin & 0.1 & 3.64 \\
\hline Metaflumizone & 0.03 & 0.82 \\
\hline Novaluron & 0.04 & 0.57 \\
\hline Total & 1.94 & 79.5 \\
\hline \multicolumn{3}{|l|}{ Option 2} \\
\hline Imidacloprid & 0.06 & 2.2 \\
\hline Thiomethoxam & 0.05 & 1.67 \\
\hline Acetamiprid & 0.05 & 1.45 \\
\hline Diafenthiuron & 0.1 & 2.53 \\
\hline Chloripyrifos & 0.39 & 10.58 \\
\hline Profenfos & 0.81 & 48.28 \\
\hline Metaflumizone & 0.03 & 0.82 \\
\hline Emamectin & 0.01 & 0.29 \\
\hline Total & 1.50 & 67.83 \\
\hline Average conventional & 1.73 & 73.67 \\
\hline \multicolumn{3}{|l|}{ GM IR cotton } \\
\hline Imidacloprid & 0.06 & 2.2 \\
\hline Thiomethoxam & 0.05 & 1.67 \\
\hline Acetamiprid & 0.05 & 1.45 \\
\hline Diafenthiuron & 0.1 & 2.53 \\
\hline Buprofezin & 0.07 & 2.55 \\
\hline Acephate & 0.63 & 15.79 \\
\hline Total & 0.97 & 26.19 \\
\hline \multicolumn{3}{|l|}{ Option 2} \\
\hline Imidacloprid & 0.06 & 1.54 \\
\hline Thiomethoxam & 0.05 & 1.67 \\
\hline Acetamiprid & 0.05 & 2.30 \\
\hline Diafenthiuron & 0.1 & 2.53 \\
\hline Total & 0.26 & 8.04 \\
\hline Weighted average GM IR cotton & 0.68 & 18.85 \\
\hline
\end{tabular}

Source: Monsanto India, AMIS Global

Note: weighted average for GM IR cotton based on insecticide usage - option $160 \%$, option $240 \%$ 


\section{Data sources (for pesticide usage data)}

\begin{tabular}{|c|c|}
\hline & Sources of data for assumptions \\
\hline US & $\begin{array}{l}\text { Gianessi \& Carpenter (1999) (Gianessi \& Carpenter, 1999) } \\
\text { Sankala \& Blumenthal (2003 and 2006) (Sankula \& Blumenthal, 2003, Sankula \& Blumenthal, 2006) } \\
\text { Johnson \& Strom (2007) (Johnson \& Strom, 2006) } \\
\text { Own analysis (2010-2015) } \\
\text { All of the above mainly for conventional regimes (based on surveys and consultations of extension advisors } \\
\text { and industry experts) } \\
\text { GFK Kynetec - private market research data on pesticide usage. Is the most comprehensive data set on } \\
\text { crop pesticide usage at the farm level and allows for disaggregation to cover biotech vs. conventional } \\
\text { crops. This source primarily used for usage on GM traits }\end{array}$ \\
\hline Argentina & $\begin{array}{l}\text { AMIS Global \& Kleffmann - private market research data on pesticide use. Is the most detailed data set on } \\
\text { crop pesticide use } \\
\text { AAPRESID (farmer producers association) - personal communications } 2007 \\
\text { Monsanto Argentina (personal communications 2005, 2007, 2009, 2010, 2011, 2012, 2013, 2014, 2015) } \\
\text { Qaim \& De Janvry (2005) (Qaim \& De Janvry, 2005) } \\
\text { Qaim \& Traxler (2002) (Qaim, 2002) }\end{array}$ \\
\hline Brazil & $\begin{array}{l}\text { AMIS Global \& Kleffmann - private market research data on crop pesticide use. Is the most detailed data } \\
\text { set on crop pesticide use } \\
\text { Monsanto Brazil (2008) (Michigan State University 2007), } \\
\text { Galveo (2009Galveo, } 2009 \text { and } 2012 \text { Galveo, 2012), plus personal communications } \\
\text { Monsanto Brazil (personal communications } 2007,2009,2011,2013,2014,2015)\end{array}$ \\
\hline Uruguay & AMIS Global and as Argentina for conventional \\
\hline Paraguay & As Argentina for conventional soybeans (over the top usage), AMIS Global for GM HT soybean \\
\hline Bolivia & As Paraguay: no country-specific data identified \\
\hline Canada & $\begin{array}{l}\text { George Morris Center (2004) (George Morris Center 2004) } \\
\text { Canola Council (2001) (Canola Council of Canada 2001) } \\
\text { Smyth et al (2008) (Smyth et al., 2011) } \\
\text { Weed Control Guide Ontario (updated annually) }\end{array}$ \\
\hline S Africa & $\begin{array}{l}\text { Monsanto S Africa (personal communications 2005, 2007, 2009, 2010, 2011, 2012, 2014, 2015) } \\
\text { Ismael et al (2002) (Ismael et al., 2002) } \\
\text { AMIS Global }\end{array}$ \\
\hline Romania & AMIS Global, Brookes (2005) (Brookes, 2005) \\
\hline Australia & $\begin{array}{l}\text { AMIS Global } \\
\text { Doyle et al (2003) (Doyle, 2005, Doyle, 2003) } \\
\text { CSIRO (2005) (Commonwealth Scientific \& Industrial Research Organisation (CSIRO 2005) } \\
\text { Monsanto Australia (personal communications 2005, 2007, 2009, 2010, 2011,2012, 2014, 2016) } \\
\text { Fisher \& Tozer (2009) (Fisher \& Tozer, 2009) }\end{array}$ \\
\hline Spain & Brookes (2003 and 2008) (Brookes, 2003, Brookes, 2008) \\
\hline China & $\begin{array}{l}\text { AMIS Global } \\
\text { Pray et al (2002) (Pray et al., 2002) } \\
\text { Monsanto China personal communication }(2007,2009,2010,2011,2013,2014,2016)\end{array}$ \\
\hline Mexico & $\begin{array}{l}\text { Monsanto Mexico (2005, 2007, 2008, 2009, 2013, 2016) (Monsanto Comercial Mexico 2015, Monsanto } \\
\text { Comercial Mexico 2013, Monsanto Comercial Mexico 2012, Monsanto Comercial Mexico 2009, } \\
\text { Monsanto Comercial Mexico 2008, Monsanto Comercial Mexico 2007, Monsanto Comercial Mexico) } \\
\text { Traxler G et al (2001) (Traxler et al., 2001) }\end{array}$ \\
\hline India & $\begin{array}{l}\text { AMIS Global } \\
\text { APCOAB }(2006) \text { (Asia-Pacific Consortium on Agricultural Biotechnology (APCoAB 2006) } \\
\text { IMRB }(2006,2007) \text { (IMRB International 2006, IMRB International 2007) } \\
\text { Monsanto India }(2007,2008,2009,2010,2011,2013,2016) \text { - personal communications }\end{array}$ \\
\hline
\end{tabular}


Appendix 3: Carbon Saving Estimates: Additional Information

US soybeans: Permanent reduction in tractor fuel consumption and reduction in carbon dioxide emissions (1996-2015)

\begin{tabular}{ccccc}
\hline & $\begin{array}{c}\text { Annual reduction based on } \\
\text { 1996 average (liters/ha) }\end{array}$ & Crop area (million ha) & Total fuel saving (million liters) & Carbon dioxide (million kg) \\
\hline 1996 & 0.00 & 25.98 & 0.00 & 0.00 \\
1997 & 0.40 & 28.33 & 11.36 & 30.33 \\
1998 & 0.80 & 29.15 & 23.38 & 62.41 \\
1999 & 0.86 & 29.84 & 25.65 & 68.50 \\
2000 & 0.92 & 30.15 & 27.66 & 73.86 \\
2001 & 1.16 & 29.99 & 34.94 & 93.28 \\
2002 & 1.41 & 29.54 & 41.72 & 111.39 \\
2003 & 1.91 & 29.71 & 56.64 & 151.23 \\
2004 & 2.40 & 30.28 & 72.69 & 194.09 \\
2005 & 2.68 & 28.88 & 77.46 & 206.82 \\
2006 & 2.96 & 30.56 & 90.46 & 241.52 \\
2007 & 3.27 & 25.75 & 84.17 & 224.73 \\
2008 & 3.51 & 30.21 & 106.06 & 283.19 \\
2009 & 3.71 & 30.91 & 114.73 & 306.33 \\
2010 & 4.11 & 31.56 & 129.58 & 345.99 \\
2011 & 5.30 & 30.05 & 159.19 & 425.04 \\
2012 & 5.63 & 30.82 & 173.59 & 463.49 \\
2013 & 5.97 & 30.70 & 183.19 & 489.12 \\
2014 & 5.97 & 33.42 & 199.41 & 532.47 \\
2015 & 5.97 & 33.12 & 197.63 & 527.67 \\
Total & & & $1,809.53$ & $4,831.45$ \\
\hline
\end{tabular}

Assumption: baseline fuel usage is the 1996 level of 36.6 liters/ha

Note: Due to rounding the cumulative totals may not exactly sum the annual totals. This applies to all tables in this appendix

US soybean: potential additional soil carbon sequestration (1996 to 2015)

\begin{tabular}{lcccc}
\hline & $\begin{array}{c}\text { Annual increase in carbon sequestered } \\
\text { based on 1996 average (kg carbon/ha) }\end{array}$ & $\begin{array}{c}\text { Crop area } \\
\text { (million ha) }\end{array}$ & $\begin{array}{c}\text { Total additional carbon } \\
\text { sequestered (million kg) }\end{array}$ & $\begin{array}{c}\text { Total additional Carbon dioxide } \\
\text { sequestered (million kg) }\end{array}$ \\
\hline 1996 & 0.0 & 26.0 & 0.00 & 0.00 \\
1997 & 1.4 & 28.3 & 39.33 & 144.35 \\
1998 & 2.8 & 29.1 & 80.93 & 297.02 \\
1999 & 3.1 & 29.8 & 91.02 & 334.06 \\
2000 & 3.3 & 30.1 & 100.23 & 367.85 \\
2001 & 4.3 & 30.0 & 127.80 & 469.04 \\
2002 & 5.2 & 29.5 & 153.56 & 563.58 \\
2003 & 7.0 & 29.7 & 208.80 & 766.29 \\
2004 & 8.9 & 30.3 & 268.21 & 984.34 \\
2005 & 10.0 & 28.9 & 289.94 & $1,064.08$ \\
2006 & 11.2 & 30.6 & 342.60 & $1,257.35$ \\
2007 & 12.4 & 25.8 & 319.96 & $1,174.25$ \\
2008 & 13.5 & 30.2 & 406.34 & $1,491.28$ \\
2009 & 14.3 & 30.9 & 441.73 & $1,621.16$ \\
2010 & 15.7 & 31.6 & 495.86 & $1,819.80$ \\
2011 & 20.6 & 30.1 & 617.90 & $2,267.71$ \\
2012 & 22.0 & 30.8 & 676.92 & $2,484.29$ \\
2013 & 23.4 & 30.7 & 717.28 & $2,632.42$ \\
2014 & 23.4 & 33.4 & 780.85 & $2,865.63$ \\
2015 & 23.4 & 33.1 & 773.82 & $2,839.91$ \\
Total & & & $6,933.08$ & $25,444.41$ \\
\hline
\end{tabular}

Assumption: carbon sequestration remains at the 1996 level of $-102.9 \mathrm{~kg}$ carbon/ha/year 
Argentine soybean: permanent reduction in tractor fuel consumption and reduction in carbon dioxide emissions (1996-2015)

\begin{tabular}{rcrrr}
\hline & $\begin{array}{c}\text { Annual reduction based on } 1996 \\
\text { average of 39.1 (liters/ha) }\end{array}$ & Crop area (million ha) & Total fuel saving (million liters) & Carbon dioxide (million kg) \\
\hline 1996 & 0.0 & 5.9 & 0.0 & 0.00 \\
1997 & 2.3 & 6.4 & 14.7 & 39.16 \\
1998 & 3.1 & 7.0 & 21.5 & 57.39 \\
1999 & 2.7 & 8.2 & 21.9 & 58.54 \\
2000 & 3.0 & 10.6 & 31.6 & 84.45 \\
2001 & 5.8 & 11.5 & 67.2 & 179.41 \\
2002 & 8.3 & 13.0 & 107.3 & 286.57 \\
2003 & 9.8 & 13.5 & 132.2 & 352.90 \\
2004 & 11.7 & 14.3 & 167.4 & 447.02 \\
2005 & 10.7 & 15.2 & 163.0 & 435.19 \\
2006 & 11.0 & 16.2 & 177.4 & 473.74 \\
2007 & 12.3 & 16.6 & 204.2 & 545.15 \\
2008 & 13.7 & 16.8 & 230.4 & 615.13 \\
2009 & 13.2 & 18.6 & 245.9 & 656.53 \\
2010 & 13.7 & 18.2 & 249.8 & 667.06 \\
2011 & 14.3 & 18.6 & 265.5 & 709.00 \\
2012 & 14.3 & 19.4 & 276.3 & 737.58 \\
2013 & 14.3 & 19.8 & 282.0 & 752.83 \\
2014 & 14.3 & 19.8 & 282.4 & 753.97 \\
2015 & 14.3 & 19.4 & 277.0 & 739.49 \\
Total & & & $\mathbf{3 , 2 1 7 . 7}$ & $\mathbf{8 , 5 9 1 . 1}$ \\
\hline
\end{tabular}

Note: based on 21.89 liters/ha for NT and 49.01 liters/ha for CT

Argentine soybean: potential additional soil carbon sequestration (1996 to 2015)

\begin{tabular}{lcccc}
\hline & $\begin{array}{c}\text { Annual increase in carbon sequestered } \\
\text { based on 1996 average (kg carbon/ha) }\end{array}$ & $\begin{array}{c}\text { Crop area } \\
\text { (million ha) }\end{array}$ & $\begin{array}{c}\text { Total additional carbon } \\
\text { sequestered (million kg) }\end{array}$ & $\begin{array}{c}\text { Total additional Carbon dioxide } \\
\text { sequestered (million kg) }\end{array}$ \\
\hline 1996 & 0.0 & 5.91 & 0.0 & 0.0 \\
1997 & 16.92 & 6.39 & 108.17 & 396.98 \\
1998 & 22.80 & 6.95 & 158.52 & 581.78 \\
1999 & 19.77 & 8.18 & 161.68 & 593.38 \\
2000 & 22.03 & 10.59 & 233.27 & 856.09 \\
2001 & 43.09 & 11.50 & 495.53 & $1,818.58$ \\
2002 & 61.05 & 12.96 & 791.51 & $2,904.83$ \\
2003 & 72.20 & 13.50 & 974.71 & $3,577.19$ \\
2004 & 86.07 & 14.34 & $1,234.69$ & $4,531.31$ \\
2005 & 79.08 & 15.20 & $1,202.00$ & $4,411.35$ \\
2006 & 81.02 & 16.15 & $1,308.48$ & $4,802.13$ \\
2007 & 90.79 & 16.59 & $1,505.72$ & $5,526.00$ \\
2008 & 101.33 & 16.77 & $1,699.00$ & $6,235.34$ \\
2009 & 97.49 & 18.60 & $1,813.37$ & $6,655.06$ \\
2010 & 101.23 & 18.20 & $1,842.45$ & $6,761.81$ \\
2011 & 105.28 & 18.60 & $1,958.28$ & $7,186.90$ \\
2012 & 105.28 & 19.35 & $2,037.25$ & $7,476.69$ \\
2013 & 105.28 & 19.75 & $2,079.36$ & $7,631.24$ \\
2014 & 105.28 & 19.78 & $2,082.52$ & $7,642.83$ \\
2015 & 105.28 & 19.40 & $2,042.51$ & $7,496.01$ \\
Total & & & $\mathbf{2 3}, 729.02$ & $87,085.50$ \\
\hline
\end{tabular}

Assumption: NT $=+175 \mathrm{~kg}$ carbon $/ \mathrm{ha} / \mathrm{yr}$, Conventional Tillage $\mathrm{CT}=-25 \mathrm{~kg}$ carbon $/ \mathrm{ha} / \mathrm{yr}$ 
Brazil (3 southernmost states) soybean: permanent reduction in tractor fuel consumption and reduction in carbon dioxide emissions (1997-2015)

\begin{tabular}{rcccr}
\hline & $\begin{array}{c}\text { Annual reduction based on } 1997 \\
\text { average of 40.9 (liters/ha) }\end{array}$ & Crop area (million ha) & $\begin{array}{c}\text { Total fuel saving } \\
\text { (million liters) }\end{array}$ & $\begin{array}{c}\text { Carbon dioxide } \\
\text { (million kg) }\end{array}$ \\
\hline 1997 & 0.00 & 6.19 & 0.00 & 0.00 \\
1998 & 1.36 & 6.12 & 8.30 & 22.15 \\
1999 & 2.71 & 6.05 & 16.40 & 43.80 \\
2000 & 4.07 & 5.98 & 24.34 & 65.00 \\
2001 & 5.42 & 6.84 & 37.09 & 99.03 \\
2002 & 6.78 & 7.49 & 50.76 & 135.53 \\
2003 & 8.14 & 8.21 & 66.83 & 178.43 \\
2004 & 9.49 & 8.59 & 81.52 & 217.65 \\
2005 & 10.85 & 8.30 & 89.98 & 240.26 \\
2006 & 12.20 & 8.25 & 100.65 & 268.73 \\
2007 & 12.20 & 8.19 & 99.89 & 266.71 \\
2008 & 13.56 & 8.23 & 111.56 & 297.86 \\
2009 & 14.37 & 8.90 & 127.94 & 341.60 \\
2010 & 14.92 & 9.13 & 136.24 & 363.75 \\
2011 & 14.92 & 9.11 & 135.83 & 362.66 \\
2012 & 5.46 & 9.88 & 152.79 & 407.95 \\
2013 & 16.27 & 10.49 & 170.74 & 455.87 \\
2014 & 16.27 & 11.07 & 180.19 & 481.12 \\
2015 & 16.27 & 11.54 & 187.77 & 501.35 \\
Total & & & $1,778.82$ & $4,749.45$ \\
\hline
\end{tabular}

Note: based on 21.89 liters/ha for NT and RT and 49.01 liters/ha for CT

Brazil (3 southernmost states) soybean: potential additional soil carbon sequestration (1997 to 2015)

\begin{tabular}{ccccc}
\hline & $\begin{array}{c}\text { Annual increase in carbon sequestered } \\
\text { based on 1997 average (kg carbon/ha) }\end{array}$ & $\begin{array}{c}\text { Crop area } \\
\text { (million ha) }\end{array}$ & $\begin{array}{c}\text { Total addition carbon } \\
\text { sequestered (million kg) }\end{array}$ & $\begin{array}{c}\text { Total addition Carbon dioxide } \\
\text { sequestered (million kg) }\end{array}$ \\
\hline 1997 & 0.0 & 6.2 & 0.00 & 0.00 \\
1998 & 10.0 & 6.1 & 61.19 & 224.57 \\
1999 & 20.0 & 6.0 & 120.98 & 444.00 \\
2000 & 30.0 & 6.0 & 179.52 & 658.84 \\
2001 & 40.0 & 6.8 & 273.52 & $1,003.82$ \\
2002 & 50.0 & 7.5 & 374.35 & $1,373.86$ \\
2003 & 60.0 & 8.2 & 492.84 & $1,808.72$ \\
2004 & 70.0 & 8.6 & 601.16 & $2,206.26$ \\
2005 & 80.0 & 8.3 & 663.60 & $2,435.41$ \\
2006 & 90.0 & 8.2 & 742.23 & $2,723.98$ \\
2007 & 90.0 & 8.2 & 736.65 & $2,703.51$ \\
2008 & 100.0 & 8.2 & 822.70 & $3,019.31$ \\
2009 & 106.0 & 8.9 & 943.51 & $3,462.67$ \\
2010 & 110.0 & 9.1 & $1,004.69$ & $3,687.19$ \\
2011 & 110.0 & 9.1 & $1,001.67$ & $3,676.13$ \\
2012 & 114.0 & 9.9 & $1,126.76$ & $4,135.23$ \\
2013 & 120.0 & 10.5 & $1,259.12$ & $4,620.99$ \\
2014 & 120.0 & 11.1 & $1,328.89$ & $4,877.02$ \\
2015 & 120.0 & 11.5 & $1,384.75$ & $5,082.04$ \\
Total & & & $13,118.13$ & $48,143.55$ \\
\hline
\end{tabular}

Assumption: NT/RT $=+175 \mathrm{~kg}$ carbon $/ \mathrm{ha} / \mathrm{yr}, \mathrm{CT}=-25 \mathrm{~kg}$ carbon $/ \mathrm{ha} / \mathrm{yr}$ 
US maize: permanent reduction in tractor fuel consumption and reduction in carbon dioxide emissions (1998-2015)

\begin{tabular}{rrrrr}
\hline & $\begin{array}{c}\text { Annual reduction based on } \\
\text { 1997 average (liters/ha) }\end{array}$ & Crop area (million ha) & Total fuel saving (million liters) & Carbon dioxide (million kg) \\
\hline 1997 & 0.00 & 32.19 & 0.00 & 0.00 \\
1998 & -0.30 & 32.44 & -9.58 & -25.57 \\
1999 & -0.14 & 31.32 & -4.43 & -11.84 \\
2000 & 0.01 & 32.19 & 0.39 & 1.03 \\
2001 & 0.11 & 30.64 & 3.30 & 8.81 \\
2002 & 0.20 & 31.93 & 6.50 & 17.34 \\
2003 & 0.31 & 31.81 & 10.00 & 26.71 \\
2004 & 0.43 & 32.47 & 13.82 & 36.90 \\
2005 & 0.78 & 33.10 & 25.85 & 69.01 \\
2006 & 1.14 & 31.70 & 36.02 & 96.18 \\
2007 & 1.47 & 37.88 & 55.82 & 149.05 \\
2008 & 1.34 & 31.82 & 42.72 & 114.06 \\
2009 & 2.18 & 32.21 & 70.34 & 187.80 \\
2010 & 2.73 & 32.78 & 89.53 & 239.05 \\
2011 & 3.22 & 34.35 & 110.60 & 295.29 \\
2012 & 3.71 & 35.36 & 131.10 & 350.03 \\
2013 & 3.95 & 35.48 & 140.20 & 374.33 \\
2014 & 4.20 & 33.64 & 141.16 & 376.91 \\
2015 & 4.44 & 32.68 & 145.09 & 387.39 \\
Total & & & $1,008.43$ & $2,692.50$ \\
\hline
\end{tabular}

Assumption: baseline fuel usage is the 1997 level of 46.6 liters/ha

US maize: potential additional soil carbon sequestration (1998 to 2015)

\begin{tabular}{lccrr}
\hline & $\begin{array}{c}\text { Annual increase in carbon sequestered } \\
\text { based on 1997 average (kg carbon/ha) }\end{array}$ & $\begin{array}{c}\text { Crop area } \\
\text { (million ha) }\end{array}$ & $\begin{array}{c}\text { Additional carbon } \\
\text { sequestered (million kg) }\end{array}$ & $\begin{array}{c}\text { Additional carbon dioxide } \\
\text { sequestered (million kg) }\end{array}$ \\
\hline 1997 & 0.0 & 32.2 & 0.00 & 0.00 \\
1998 & -2.8 & 32.4 & -90.93 & -333.70 \\
1999 & -1.2 & 31.3 & -36.32 & -133.29 \\
2000 & 0.5 & 32.2 & 15.56 & 57.11 \\
2001 & 1.5 & 30.6 & 44.90 & 164.78 \\
2002 & 2.4 & 31.9 & 78.15 & 286.81 \\
2003 & 3.6 & 31.8 & 114.19 & 419.09 \\
2004 & 4.7 & 32.5 & 153.64 & 563.84 \\
2005 & 8.4 & 33.1 & 277.58 & $1,018.73$ \\
2006 & 12.0 & 31.7 & 381.73 & $1,400.94$ \\
2007 & 15.4 & 37.9 & 585.14 & $2,147.48$ \\
2008 & 14.1 & 31.8 & 448.24 & $1,645.05$ \\
2009 & 22.7 & 32.2 & 731.42 & $2,684.32$ \\
2010 & 28.3 & 32.8 & 928.21 & $3,406.54$ \\
2011 & 33.3 & 34.4 & $1,144.48$ & $4,200.22$ \\
2012 & 38.3 & 35.4 & $1,354.80$ & $4,972.11$ \\
2013 & 40.8 & 35.5 & $1,448.04$ & $5,314.33$ \\
2014 & 43.3 & 33.6 & $1,457.30$ & $5,348.30$ \\
2015 & 45.8 & 32.7 & $1,497.16$ & $5,494.56$ \\
Total & & & $\mathbf{1 0 , 5 3 3 . 3 0}$ & $3,657.22$ \\
\hline
\end{tabular}

Assumption: carbon sequestration remains at the 1997 level of $80.1 \mathrm{~kg}$ carbon/ha/year 
Canadian canola: permanent reduction in tractor fuel consumption and reduction in carbon dioxide emissions (1996-2015)

\begin{tabular}{rcccc}
\hline & $\begin{array}{c}\text { Annual reduction based on } \\
\text { 1996 average 30.6 (I/ha) }\end{array}$ & Crop area (million ha) & Total fuel saving (million liters) & Carbon dioxide (million kg) \\
\hline 1996 & 0.0 & 3.5 & 0.0 & 0.00 \\
1997 & 0.9 & 4.9 & 4.3 & 11.51 \\
1998 & 0.9 & 5.4 & 4.8 & 12.83 \\
1999 & 0.9 & 5.6 & 4.9 & 13.15 \\
2000 & 0.9 & 4.9 & 4.3 & 11.48 \\
2001 & 1.8 & 3.8 & 6.7 & 17.89 \\
2002 & 2.7 & 3.3 & 8.7 & 23.12 \\
2003 & 3.5 & 4.7 & 16.6 & 44.32 \\
2004 & 4.4 & 4.9 & 21.9 & 58.35 \\
2005 & 5.3 & 5.5 & 29.2 & 77.85 \\
2006 & 6.2 & 5.2 & 32.5 & 86.64 \\
2007 & 6.5 & 5.9 & 38.7 & 103.36 \\
2008 & 7.1 & 6.5 & 46.0 & 122.77 \\
2009 & 8.0 & 6.4 & 50.8 & 135.59 \\
2010 & 8.8 & 6.5 & 57.7 & 153.93 \\
2011 & 8.9 & 7.5 & 66.1 & 176.54 \\
2012 & 8.9 & 8.6 & 76.0 & 202.86 \\
2013 & 8.9 & 7.8 & 69.1 & 184.61 \\
2014 & 8.9 & 8.3 & 73.9 & 197.17 \\
2015 & 8.9 & 8.1 & 71.5 & 191.00 \\
Total & & & 683.5 & $\mathbf{1 , 8 2 5 . 0 0}$ \\
\hline
\end{tabular}

Note: fuel usage NT/RT $=17.3$ liters/ha CT $=35$ liters/ha

Canadian canola: potential additional soil carbon sequestration (1996 to 2015)

\begin{tabular}{lccrr}
\hline & $\begin{array}{c}\text { Annual increase in carbon sequestered based on } \\
\text { 1996 average (kg carbon/ha) }\end{array}$ & $\begin{array}{c}\text { Crop area } \\
\text { (million ha) }\end{array}$ & $\begin{array}{r}\text { Total carbon sequestered } \\
\text { (million kg) }\end{array}$ & $\begin{array}{c}\text { Carbon dioxide } \\
(\mathrm{million} \text { kg) }\end{array}$ \\
\hline 1996 & 0.0 & 3.5 & 0.00 & 0.00 \\
1997 & 3.3 & 4.9 & 15.83 & 58.09 \\
1998 & 3.3 & 5.4 & 17.64 & 64.75 \\
1999 & 3.3 & 5.6 & 18.08 & 66.37 \\
2000 & 3.3 & 4.9 & 15.79 & 57.96 \\
2001 & 6.5 & 3.8 & 24.60 & 90.30 \\
2002 & 9.8 & 3.3 & 31.80 & 116.71 \\
2003 & 13.0 & 4.7 & 60.96 & 223.72 \\
2004 & 16.3 & 4.9 & 80.26 & 294.55 \\
2005 & 19.5 & 5.5 & 107.07 & 392.96 \\
2006 & 22.8 & 5.2 & 119.17 & 437.36 \\
2007 & 24.1 & 5.9 & 142.16 & 521.72 \\
2008 & 26.0 & 6.5 & 168.86 & 619.71 \\
2009 & 29.3 & 6.4 & 186.50 & 684.44 \\
2010 & 32.5 & 6.5 & 211.72 & 777.00 \\
2011 & 32.5 & 7.5 & 242.81 & 891.10 \\
2012 & 32.5 & 8.6 & 279.01 & $1,023.98$ \\
2013 & 32.5 & 7.8 & 253.91 & 931.84 \\
2014 & 32.5 & 8.3 & 271.17 & 995.23 \\
2015 & 32.5 & 8.1 & 262.70 & 964.10 \\
Total & & & $\mathbf{2 , 5 1 0 . 0 5}$ & $9,211.89$ \\
\hline
\end{tabular}

Note: $\mathrm{NT} / \mathrm{RT}=+55 \mathrm{~kg}$ of carbon/ha/yr CT $=-10 \mathrm{~kg}$ of carbon/ha/yr 
Permanent reduction in global tractor fuel consumption and carbon dioxide emissions resulting from the cultivation of GM IR cotton (1996-2015)

\begin{tabular}{cccccc}
\hline & $\begin{array}{c}\text { Total cotton area in GM IR growing } \\
\text { countries excluding Burkina } \\
\text { Faso, India, Pakistan, Myanmar, } \\
\text { Sudan and China (million ha) }\end{array}$ & $\begin{array}{c}\text { GM IR area excluding } \\
\text { Burkina Faso, India, Pakistan, } \\
\text { Myanmar, Sudan and } \\
\text { China (million ha) }\end{array}$ & $\begin{array}{c}\text { Total spray } \\
\text { runs saved } \\
\text { (million ha) }\end{array}$ & $\begin{array}{c}\text { Fuel saving } \\
\text { (million } \\
\text { liters) }\end{array}$ & $\begin{array}{c}\text { CO2 emissions } \\
\text { saved } \\
\text { (million kg) }\end{array}$ \\
\hline 1996 & 6.64 & 0.86 & 3.45 & 2.90 & 7.73 \\
1997 & 6.35 & 0.92 & 3.67 & 3.09 & 8.24 \\
1998 & 7.20 & 1.05 & 4.20 & 3.53 & 9.43 \\
1999 & 7.42 & 2.11 & 8.44 & 7.09 & 18.92 \\
2000 & 7.29 & 2.43 & 9.72 & 8.17 & 21.81 \\
2001 & 7.25 & 2.55 & 10.18 & 8.55 & 22.84 \\
2002 & 6.36 & 2.17 & 8.69 & 7.30 & 19.49 \\
2003 & 5.34 & 2.17 & 8.70 & 7.30 & 19.50 \\
2004 & 6.03 & 2.79 & 11.17 & 9.38 & 25.05 \\
2005 & 6.34 & 3.21 & 12.84 & 10.78 & 28.79 \\
2006 & 7.90 & 3.94 & 15.75 & 13.23 & 35.33 \\
2007 & 6.07 & 3.25 & 12.99 & 10.91 & 29.14 \\
2008 & 4.51 & 2.54 & 10.16 & 8.53 & 22.78 \\
2009 & 5.33 & 2.96 & 11.83 & 9.94 & 26.54 \\
2010 & 7.13 & 4.59 & 18.37 & 15.43 & 41.21 \\
2011 & 6.61 & 4.43 & 17.70 & 14.87 & 39.71 \\
2012 & 5.72 & 4.07 & 16.30 & 13.69 & 36.55 \\
2013 & 5.29 & 3.75 & 15.01 & 12.61 & 33.66 \\
2014 & 5.57 & 4.20 & 16.80 & 14.11 & 37.66 \\
2015 & 5.00 & 3.95 & 15.78 & 13.26 & 35.40 \\
Total & & & 231.75 & 194.67 & 519.78 \\
\hline
\end{tabular}

Notes: assumptions: 4 applications per ha, 0.84 liters/ha of fuel per insecticide application. 